DIW BERLIN

Discussion Papers
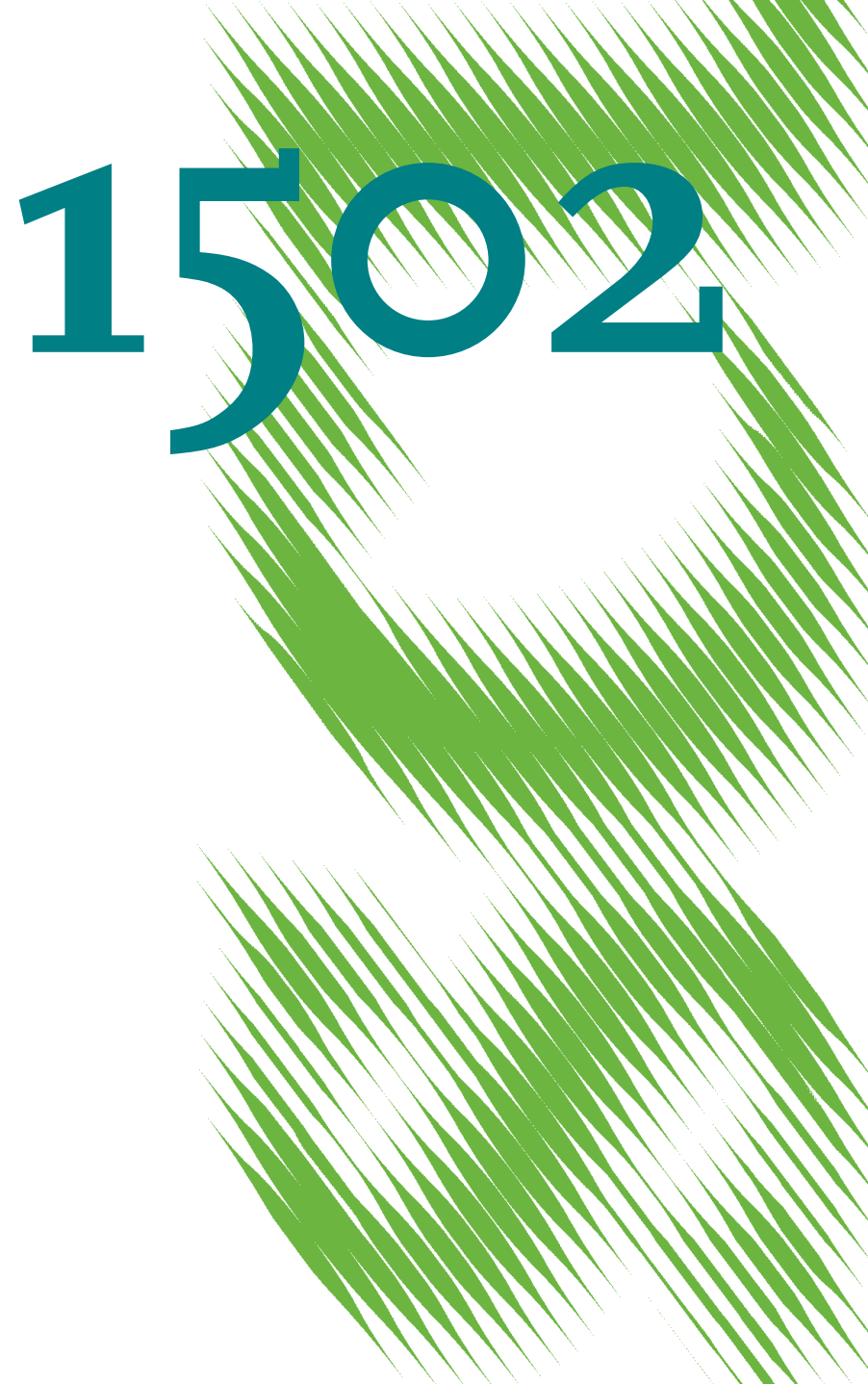

MMl

MMMMMMMMMM

\title{
The Top Tail of the Wealth Distribution in Germany, France, Spain, and Greece
}


Opinions expressed in this paper are those of the author(s) and do not necessarily reflect views of the institute.

IMPRESSUM

(C) DIW Berlin, 2015

DIW Berlin

German Institute for Economic Research

Mohrenstr. 58

10117 Berlin

Tel. +49 (30) $89789-0$

Fax +49 (30) $89789-200$

http://www.diw.de

ISSN electronic edition 1619-4535

Papers can be downloaded free of charge from the DIW Berlin website:

http://www.diw.de/discussionpapers

Discussion Papers of DIW Berlin are indexed in RePEc and SSRN:

http://ideas.repec.org/s/diw/diwwpp.html

http://www.ssrn.com/link/DIW-Berlin-German-Inst-Econ-Res.html 


\title{
The Top Tail of the Wealth Distribution in Germany, France, Spain, and Greece
}

\author{
Stefan Bach \\ DIW Berlin and Universität Potsdam (sbach@diw.de)
}

Andreas Thiemann

DIW Berlin (athiemann@diw.de)

Aline Zucco

Universität Erlangen-Nürnberg (aline.zucco@googlemail.com)

September 2, 2015

\begin{abstract}
We analyze the top tail of the wealth distribution in Germany, France, Spain, and Greece based on the Household Finance and Consumption Survey (HFCS). Since top wealth is likely to be underrepresented in household surveys we integrate the big fortunes from rich lists, estimate a Pareto distribution, and impute the missing rich. Instead of the Forbes list we mainly rely on national rich lists since they represent a broader base for the big fortunes. As a result, the top percentile share of household wealth in Germany jumps up from 24 percent in the HFCS alone to 33 percent after top wealth imputation. For France and Spain we find only a small effect of the imputation since rich households are better captured in the survey. The results for Greece are ambiguous since the data do not show clear concentration patterns.
\end{abstract}

Keywords: Wealth distribution, missing rich, Pareto distribution.

JEL Classification: D31, C46, C81.

Acknowledgement: We thank Peter Haan, Charlotte Bartels, Margit Schratzenstaller-Altzinger, Markus Grabka and Christian Westermeier for helpful discussions and valuable comments. The usual disclaimer applies. 


\section{Introduction}

Rising inequality in income and wealth is increasingly gaining attention, both in the public debate and in academic research. The widespread discussion around the study of Piketty (2013) focusses on the concentration at the top and the underlying trends in modern capitalism. Economists and financial analysts are aware of increasing heterogeneity in income and wealth and their consequences for financial stability, savings and investment, employment and growth, and social cohesion. Against the backdrop of tax policy trends to reduce progressivity over the last decades (Förster et al., 2014) and high budget deficits after the financial crisis, tax increases on high capital income and top wealth are endorsed in many countries or even implemented. Thus, proper information on the distribution of capital income and wealth, in particular at the top, becomes increasingly important. However, we are still far from really understanding what is going on at the top tail of the wealth distribution. This study aims to shed light on the top wealth distribution in Germany, France, Spain, and Greece by integrating household survey data and rich lists of the big fortunes.

Household surveys describe the wealth distribution by socio-demographic characteristics (Davis et al., 2010). The Eurosystem's Household Finance and Consumption Survey (HFCS) (ECB, 2013a), conducted in most countries of the Eurozone, provides comprehensive information on the wealth distribution in international comparison. For instance, the data reveal that Germany has one of the most unequal wealth distributions in Europe. However, with respect to the top wealth distribution, household surveys are plagued with serious drawbacks. Since personal wealth is typically much more concentrated than income it is hard to represent the top wealth distribution by small-scale voluntary surveys. The potential non-observation bias, i.e. the lack of reliability due to small sample sizes, could be only partly reduced by oversampling of the rich households. Moreover, a non-response bias is likely to occur as response rates presumably decrease with high income and wealth, in particular at the top (Vermeulen, 2014).

A viable solution to better capture the missing rich would be to estimate the top wealth concentration by relying on functional form assumptions on the shape of the top tail distribution. Traditionally, the Pareto distribution is used as it approximates well the top tail of income and wealth (Davies and Shorrocks, 1999). In addition, more complex functional forms might be used (Clauset et al., 2009, Burkhauser et al., 2012, Brzezinski, 2013). Yet, the problem of biased wealth concentration remains if top wealth households are substantially underrepre- 
sented in survey data. A further alternative would be to use additional information at least for the super-rich households which is available for many countries by listings provided by business media. The most popular of these rich lists is the World's billionaires, published by the US economic magazine Forbes (2014). For larger countries there are national lists covering households or families up to a net wealth of hundreds of millions of dollars. Researchers used such lists to check top wealth estimates based on survey data or to augment survey data (see, e.g., Davies, 1993 for Canada, Bach et al., 2014 for Germany, or Eckerstorfer et al., 2015 for Austria).

Vermeulen (2014) provides a straightforward method to combine household survey data on wealth with rich lists of the big fortunes to jointly estimate a Pareto distribution for the top tail of wealth. He uses the US Survey of Consumer Finances (SCF) and the HFCS for the Eurozone countries and augments it with the Forbes list. He shows for the USA and nine Eurozone countries the potential underrepresentation of top wealth in the survey data. According to his results, differential non-response problems seem to be rather high in a number of Eurozone countries, in particular in Germany. This leads to underestimation of the top wealth shares when using only survey data to estimate top wealth without extreme tail observations.

We extend the study by Vermeulen (2014) and use country specific information in addition to the Forbes list. In particular, we construct an integrated database for Germany, France, Spain, and Greece that better represents the top wealth concentration. We use the HFCS survey data, combined with the Forbes billionaires and national lists of the richest persons or families of these countries, provided by the media. Based on these data we refer to the approach of Vermeulen (2014) to jointly estimate a Pareto distribution for each country and impute the missing rich. Instead of the Forbes list we mainly rely on national rich lists since they represent a broader base for the big fortunes. Especially for France and Spain the Forbes list contains only few observations. The resulting database could be used for detailed distribution analyses or microsimulation studies.

Our estimations are broadly in line with the findings of Vermeulen (2014). However, the inclusion of the national rich lists instead of the Forbes list substantially increases the top wealth concentration. We find that the top percentile share of household wealth in Germany jumps up from 24 percent based on the HFCS alone to 33 percent after top wealth imputation. The Gini coefficient for the wealth distribution increases from 0.75 to 0.78 . For France and Spain we find only a small effect of the imputation since rich households are better captured in the survey. The top percentile share of net wealth increases from 18 to 21 percent in 
France, and from 15 to 17 percent in Spain. The Gini coefficient increases from 0.67 to 0.69 in France and from 0.57 to 0.58 in Spain. The results for Greece are ambiguous since the data do not show clear concentration patterns.

The remainder of the paper proceeds as follows: Section 2 describes the data used. The methodology of estimation and imputation of the top wealth distribution is presented in Section 3. Section 4 shows the results of the top wealth imputation on the wealth distribution. Section 5 concludes.

\section{Data}

This study on the wealth distribution in Germany, France, Spain, and Greece is based on three data sets: The Eurosystem's Household Finance and Consumption Survey (HFCS) and rich lists for these countries. In this section we will have a deeper look at these data sets.

\subsection{Household Finance and Consumption Survey (HFCS)}

The HFCS is a decentralized household survey for the Eurozone. It is conducted by the national central banks of the Eurosystem. The idea of this survey is to collect information about the consumption behavior and the financial situations of households in the Eurozone countries. Our analysis bases on the information of the first wave which was collected between 2008 and 2011 (ECB, 2013a: 8). In future, the survey shall be conducted every two to three years. The data contains information of households in Belgium, Germany, Spain, France, Italy, Greece, Cyprus, Luxembourg, Malta, Netherlands, Austria, Portugal, Slovenia, Slovakia, and Finland. The HFCS oversamples wealthy households to deal with potential nonobservation bias, whereas the criteria for oversampling vary across countries (ECB, 2013a: 9).

Table 1 shows the gross sample size, the number of interviewed households, the response rate and the effective oversampling rate of the top 10 percent by country. The effective oversampling rate describes to which extent the ratio of the top 10 percent is oversampled compared to its share in the population (ECB, 2013a: 36). The samples are weighted in a way that the total number corresponds to the official number of households which bases on adjusted information from, depending on the country, population registers and statistics, current population surveys, household and labor force surveys, social security registers, and tax registers (ECB, 2013b: 13). For item non-response, i.e. participants refuse or are unable to answer certain questions, the editors of the database provide five implicates inserted by multiple imputation (ECB, 2013a: 39). For our analysis we use the mean of the five implicates. We have not 
yet analyzed the impact of the multiple imputation that might increase the standard errors somewhat.

Table 1: Sample Size and Oversampling Rate in the HFCS

\begin{tabular}{|l|cccc|}
\hline & $\begin{array}{c}\text { Gross } \\
\text { sample size }\end{array}$ & $\begin{array}{c}\text { Interviewed } \\
\text { households }\end{array}$ & $\begin{array}{c}\text { Response } \\
\text { rate, } \\
\text { in percent }\end{array}$ & $\begin{array}{c}\text { Effective } \\
\text { oversampling } \\
\text { rate of the } \\
\text { top 10\%, } \\
\text { in percent }\end{array}$ \\
\hline Austria & 4,436 & 2,380 & 56 & 1 \\
Belgium & 11,376 & 2,364 & 22 & 47 \\
Cyprus & 3,938 & 1,237 & 31 & 81 \\
Finland & 13,525 & 10,989 & 82 & 68 \\
France & 21,627 & 15,006 & 69 & 129 \\
Germany & 20,501 & 3,565 & 19 & 117 \\
Greece & 6,354 & 2,971 & 47 & -2 \\
Italy & 15,592 & 7,951 & 52 & 4 \\
Luxembourg & 5,000 & 950 & 20 & 55 \\
Malta & 3,000 & 843 & 30 & -5 \\
Netherlands & 2,263 & 1,301 & 58 & 87 \\
Portugal & 8,000 & 4,404 & 64 & 16 \\
Slovakia & $\mathrm{n} . \mathrm{a}$. & 2,057 & $\mathrm{n} . \mathrm{a.}$ & -11 \\
Slovenia & 965 & 343 & 36 & 22 \\
Spain & 11,782 & 6,197 & 57 & 192 \\
\hline
\end{tabular}

Source: ECB (2013a: 41).

Nevertheless, it must be mentioned that a decentralized survey is also combined with the difficulty to compare cross-country results. By comparing the survey methodology of the countries of interest, we see some country specific differences. First of all, the response rate between both countries varies from 69.0 percent in France to 18.7 percent in Germany. This is mainly caused by the fact that the survey participation in France is compulsory, while in the three other countries it is voluntary (ECB, 2013a: 41). Furthermore, Germany and Spain exclude homeless and the institutionalized population, Greece in addition excludes also smaller villages while France excludes the institutionalized population only (ECB, 2013a: 33). The most important difference for our analysis might be the oversampling of the rich. The basis for the oversampling in Germany is the geographic information about taxable income, whereas the French oversampling is based on the individual information about taxable net wealth. Finally, the surveys differ in time and duration of the reference period. While the Spanish survey refers to the period from November 2008 to July 2009, the relevant period for the 
Greek fieldwork is from June to September 2009. In France the survey was conducted between October 2009 and February 2010, while the reference period in Germany is September 2010 to July 2011 (Tiefensee and Grabka, 2014). It is important to keep these differences in survey methodology in mind when comparing the results of our four countries.

The HFCS collects households' assets and liabilities in detail. Net wealth is measured as the sum of real estate properties, business properties, financial assets and corporate shares, the main household assets such as cars, less liabilities. Claims to social security or occupational and private pensions and health-care plans are not included in household net wealth. Net wealth is based on self-assessed property valuations of the survey respondents. We have no evidence of systematic biases in this respect.

\subsection{Rich lists}

Since decades, business media and researchers provide listings of the big fortunes held by the super-rich. We use the World's billionaires of Forbes (2014) and national lists of the richest persons or families of the selected countries, provided by the media. We refer to the annual issue of the rich lists for the year in which the HFCS survey was conducted in the countries (Table 2).

The reliability of these lists is contentious since the data are not surveyed by a consistent method but collected from different sources and compiled by different methods. Information is collected from public registers, financial markets, business media, and through interviews of wealthy individuals themselves. The completeness of the lists is unclear. In particular with respect to smaller fortunes which are often dominated by non-quoted corporate shares or other assets measurement errors are likely to be higher. Accordingly, the selectivity of the listings might strongly increase with lower ranks. "Heaping effects", i.e. many observations at round numbers, underline this presumption.

In many cases the wealth is reported for "families", for instance entrepreneurial families that actually might consist of many households. Especially in Germany there are many successful firms of the "German Mittelstand" or even major enterprises which are family-owned for generations. Likewise, in the other countries there are wealthy families consisting of many members. Insofar the top wealth concentration could be overrepresented in the listings. We correct the German national list by using public available information on the number of shareholders of the respective family-owned firms (see below). Moreover, we remove house- 
holds from the list that are obviously living abroad. For the other countries we disregard these issues.

The listings presumably ignore private assets or liabilities beside corporate wealth. Typically, many top-wealth households should have real estate properties and financial portfolios, thus leading to an underestimation of the top wealth concentration. In some cases, however, corporate investments might be leveraged by private debt although this would have unfavorable tax consequences.

Evaluations with administrative data from wealth taxation are rare since recurrent taxes on personal net wealth have been discarded in most OECD counties over the last decades. Among the four countries that we focus on, France and Spain still raise a recurrent wealth tax. ${ }^{1}$ Inheritance, gift and estate taxes, which still exist in the main OECD countries, only capture intergenerational transfers whose concentration deviate from personal top wealth concentration due to different numbers of heirs and anticipated inheritance by gifts and legacies. Generally, top wealth information from tax files could be strongly flawed because of explicit tax privileges, in particular for small and medium sized firms or donations to non-profit organizations, or favorable valuation procedures for real estate and business properties that systematically underestimate the market value. ${ }^{2}$

\section{manager magazin list of the richest households in Germany}

The manager magazin publishes annually a list of the richest persons or families in Germany. From 2000 to 2009 the magazine named the 300 wealthiest Germans (and their wealth), since 2010 even the 500 richest. Their net wealth is estimated based on information from archives, registers, stock markets, lawyers, asset managers and the wealthy people themselves (manager magazin, 2011). The editors of the list indicate that in some cases persons concerned claimed to be removed from the list for reasons of privacy and security.

1 Zucman (2008) uses tabulations of the French wealth tax base 1995 to analyze top wealth distribution. Alvaredo and Saez (2009) use tabulations of the Spanish wealth tax base up to 2005 to estimate top wealth shares.

2 Researchers from the US federal tax authority IRS compared the estate tax files of deceased persons and the Forbes list (Raub et al., 2010). They discovered that the list overestimated net worth by approximately 50 percent, primarily due to valuation difficulties and tax exemptions, but also due to family relations (individuals vs. couples) and other structural differences. 
Presumably, the incompleteness and selectivity of the list increase with lower ranks since there is scarce information for households holding non-quoted firms or other assets. "Heaping effects" underline this presumption (see section 3.2). Therefore, we only use the top 200 of the German list. The wealth is reported for "families" which could consist of many households in the case of firms or foundations that are family-owned firms for generations. We correct the respective observations by using public available information on the number of shareholders. This is possible for the top 150 of the list by thorough internet research. However, measurement errors might clearly remain since there is often scarce information on the ownership structure provided by financial accounts and other companies' disclosures. Generally, German entrepreneurs of the "Mittelstand" are rather reserved in providing information on their financial affairs and anxious to keep capital markets and external investors out of their firms. In the case of the lower-ranked families we generally assume 4 households per family. Moreover, we generally assume equal shares of the estimated households per family. We also remove households from the list that are obviously non-residents. The corrections are of limited impact on the descriptives of the 200 richest households (Table 2) and the top concentration analyses below.

Table 2: Summary statistics of the national rich lists in Germany, France, Spain, and Greece

In billion Euro

\begin{tabular}{|c|c|c|c|c|c|c|}
\hline Country & Rich list & $\mathrm{N}$ & Mean & Std. Dev. & Min & Max \\
\hline Germany & $m m$ 200 - corrected & 200 & 1.52 & 1.87 & 0.56 & 17 \\
& $m m$ 200 - original & 200 & 1.91 & 2.29 & 0.55 & 17 \\
& Forbes & 52 & 3.27 & 3.22 & 0.76 & 18 \\
\hline \multirow{2}{*}{ France } & Challenge 200 & 200 & 1.08 & 2.60 & 0.16 & 23 \\
& Forbes & 11 & 5.47 & 6.35 & 0.81 & 20 \\
\hline \multirow{2}{*}{ Spain } & El mundo list & 74 & 1.49 & 2.06 & 0.50 & 16 \\
& Forbes & 12 & 2.06 & 3.29 & 0.679 & 12 \\
\hline \multirow{2}{*}{ Greece } & Greek Rich list & 29 & 0.194 & 0.331 & 0.038 & 2 \\
& Forbes & 18 & 2.14 & 1.91 & 0.48 & 7 \\
\hline
\end{tabular}

Source: manager magazin (2011), the corrected mm 200 adjusts the rich list entries by the number of households per entry, Challenge (2010), El mundo (2009), Greek Rich List (2009) and Forbes (2009, 2010, 2011, 2014), own calculations. 


\section{Challenges list of the richest households in France}

Since 1996, the Challenges magazine publishes annually a list that contains the 500 richest households in France. Their net wealth is estimated based on a large database, constructed and updated by a team of journalists of Challenges. It relies on various sources of information: Public data on share ownership and accounts, investigations of the ownership structure of unlisted companies, professional publications, seminars, award ceremonies and surveys send to rich households directly (Challenges, 2012). Similar to the German case we finally use the top 100-300 observations of the Challenges (2010) list.

\section{El mundo list of the richest households in Spain}

In Spain, we rely on national rich lists compiled by the third largest newspaper el mundo. Since 2006, the newspaper publishes two lists based on the top 100 richest individuals. The first list of the top 50 "visible fortunes" is based on public information on share ownership from stock markets. The second list of the top 50 "estimated fortunes" is based on estimations of shares in unlisted companies, mainly. The estimation was based on information about purchase-sales of shares, venture capital investments and direct estimations of fortunes. The joint list for 2009 we use in the paper is based on the top 50 "visible fortunes" and the 27 top "estimated fortunes", where the last entry from the latter list reports the same net wealth as the poorest person from the first list. Hence, the final list contains the 74 richest Spanish individuals (El mundo, 2009).

\section{Greek Rich List of the richest persons in Greece}

Since 2007, the Greek Rich List magazine publishes annually a list of the wealthiest Greek individuals. Their net wealth is estimated based on public information about stock holdings, information from the Foundation of the Hellenic World and from research companies and analysts. The rich list 2009/2010 contains information about 29 wealthy Greeks (Greek Rich List, 2009/10).

\section{Forbes list of World's billionaires}

To make it on the Forbes billionaire list the personal net wealth is estimated to be above 1 billion dollar. Similar to the lists described above, Forbes reporters compiled available information on the big fortunes worldwide (Forbes, 2014). Compared to the national lists, the Forbes list seems to be more reliable as it focusses on the super-rich, for which reliable information is easier to collect. Moreover, many billionaires co-operate with the editors. How- 
ever, distortions regarding the incompleteness and selectivity of the list likely remain when comparing the Forbes list with the national lists. For our analysis we recalculate the wealth in Euro. For Greece we used the 2014 billionaire list since the 2010 list does not contain one Greek observation. As a rough estimation we deduct 20 percent of the 2014 values of wealth.

\section{Methodology of estimation and imputation of the top wealth distribution}

This section describes how we construct the adjusted wealth distribution for Germany and France. First, the theoretical background underlying the approach is briefly sketched. Based on this, we then estimate the Pareto coefficients for both countries, relying on the HFCS and the corresponding national rich lists. Finally, we impute synthetic household net wealth for the missing wealth based on the Pareto coefficients for each country.

\subsection{Theoretical background}

This paper relies on the Pareto distribution which is mostly used in the literature to approximate the top tail of the wealth distribution. ${ }^{3}$ In the following, we define the wealth threshold that determines the top tail as $w_{\text {min }}$. The tail density function of the Pareto distribution is given by

$$
f\left(w_{i}\right)= \begin{cases}\frac{\alpha w_{\min }^{\alpha}}{w_{i}^{\alpha+1}} & \text { if } w_{i} \geq w_{\min } \\ 0 & \text { if } w_{i}<w_{\min }\end{cases}
$$

where $w_{i}$ determines the wealth of household $i$ and $\alpha$ denotes the Pareto coefficient. Thus the distribution function can be estimated subject to (2) and (3):

$$
\begin{gathered}
P\left(W \leq w_{i}\right)=F\left(w_{i}\right)=\int_{w_{\text {min }}}^{w} f(t) d t=1-\left(\frac{w_{\text {min }}}{w_{i}}\right)^{\alpha} ; \forall w_{i} \geq w_{\text {min }} \\
P\left(W>w_{i}\right)=1-P\left(W \leq w_{i}\right)=\left(\frac{w_{\text {min }}}{w_{i}}\right)^{\alpha} ; \forall w_{i} \geq w_{\text {min }}
\end{gathered}
$$

Equation (3) represents the "complementary cumulative distribution function" (ccdf) which describes the probability of wealth above $w_{i}$, defined on the interval $\left[w_{\min }, \infty\right]$. The Pareto

\footnotetext{
3 For the following see Vermeulen (2014), Cowell (2009), Gabaix (2009), Clauset et al. (2009), KIeiber and Kotz (2003), Davies and Shorrocks (1999), Embrechts et al. (1997).
} 
coefficient $\alpha$, also called tail index, determines the fatness of the tail. Note that the lower $\alpha$ the fatter the tail and the more concentrated is wealth.

According to Zipf's law, which gives the inverse function of the Pareto distribution, we formalize the probability by the rank of the household wealth compared to the wealth of the other households (above $w_{\min }$ ). Therefore, households are ranked by their wealth such that the richest household in the sample above $w_{\min }$ has the rank 1 and the poorest the rank $\mathrm{n}$. In the following, the rank will be formalized as $n\left(w_{i}\right)$. The sum of households, that possess wealth higher than $w_{\text {min }}$, we call $n$. To account for the complex survey structure, we follow Vermeulen (2014: 18) and take into account the survey weights when calculating the rank of a household. The households from the corresponding national rich lists are assigned a weight of one.

This leads to (4) where the ranking and (3) are combined (Vermeulen, 2014: 17)

$$
\frac{n\left(w_{i}\right)}{n} \cong\left(\frac{w_{\min }}{w_{i}}\right)^{\alpha} ; \forall w_{i} \geq w_{\min }
$$

The Pareto coefficient $\alpha$ can be estimated by taking the logarithm of (4):

$$
\ln \frac{n\left(w_{i}\right)}{n}=-\alpha \ln \frac{w_{i}}{w_{\min }}
$$

Now, the Pareto coefficient $\alpha$ can be estimated by OLS.

In addition, Vermeulen (2014: 16) introduces a more theoretical estimator of the Pareto coefficient $\alpha$, which he calls the maximum likelihood estimator. He derives this estimator directly from (1) which is valid for a simple random sample with $\mathrm{n}$ observations. The ML estimator is given in (6)

$$
\widetilde{a_{m l}}=\left[\sum_{i=1}^{n} \frac{1}{n} \ln \left(\frac{w_{i}}{w_{\min }}\right)\right]^{-1}
$$

However, Vermeulen (2014: 16) emphasizes that this estimator is biased when the calculation is based on complex survey data. As the sampling method cannot be observed completely, the i.i.d. assumption does not apply. For this reason he recommends to use the survey weights to calculate the pseudo maximum likelihood estimator. Then, the rank is denoted subject to its weight. Thus $\mathrm{N}_{1}$ is the survey weight of the household with highest wealth, $\mathrm{N}_{2}$ the survey weight for the second richest household, ..., and $\mathrm{N}_{\mathrm{n}}$ the survey weight of the poorest house- 
hold above $w_{\min }$. $\mathrm{N}$ denotes the total amount of weights above the minimum wealth. The pseudo maximum likelihood estimate for the Pareto coefficient $\alpha$ is given by (7)

$$
\widetilde{a_{p m l}}=\left[\sum_{i=1}^{n} \frac{N_{i}}{N} \ln \left(\frac{w_{i}}{w_{\text {min }}}\right)\right]^{-1}
$$

\subsection{Estimation of the Pareto coefficients}

To calculate values of $\alpha$, we combine the HFCS data with information from national rich lists or from the Forbes World's Billionaires list. As depicted by equation (5), the estimation of $\alpha$ depends on how we set $w_{\min }$ and further, according to our integration approach, on the specification of the rich list data. To obtain the proper cut-off point within the HFCS data we refer to the distinctive property of the Pareto distribution that the average wealth $w_{m}$ above any wealth threshold $w$ is a constant multiple of that threshold, which is labelled as "van der Wijk's law" (see Cowell, 2009, Embrechts et al., 1997). The coefficient of the "mean excess function" $w_{m} / w$ is labelled as inverted Pareto-Lorenz coefficient $\beta$ and equals to $\alpha /(\alpha-1)$. Based on the HFCS data, we plot the coefficient $w_{m} / w$ for wealth thresholds above 100,000 Euros for the four countries in Figure 1 - Figure 4, given in linear scale up to 1 million Euros and in log scale up to 20 million Euros. The graphs suggest a good representation of the Pareto distribution for household wealth above 500,000 Euros, which is around the $90 \%$ percentile in Germany, France, and Spain. ${ }^{4}$ Therefore, we set the cut-off point of the Pareto distribution to 500,000 Euros. We also use this cut-off point for Greece, although there is no clear stable trend of $w_{m} / w$.

4 Eckerstorfer et al. (2015) propose an advanced method to obtain the cut-off point above which wealth follows a Pareto distribution. They suggest identifying suitable parameter combinations of maximum-likelihood estimates and goodness-of-fit tests. 
Figure 1: Ratio mean wealth above $w$ divided by $w, w_{m} / w$, Germany

Linear scale

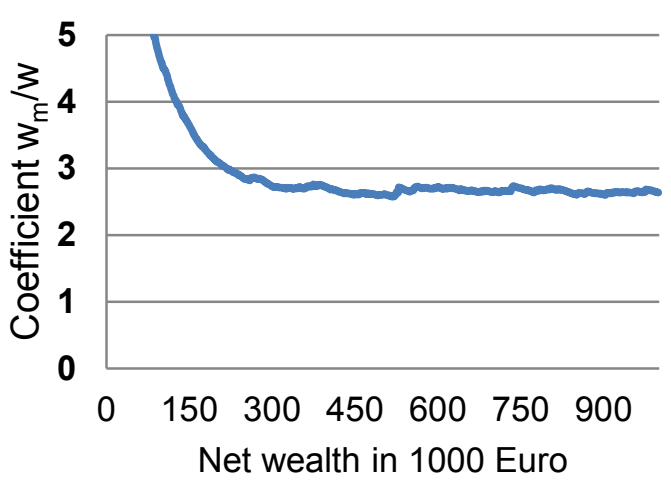

Logarithmic scale

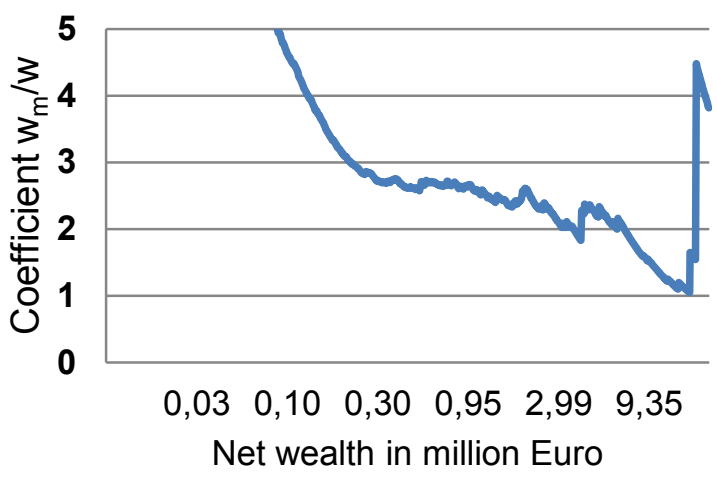

Source: HFCS, own calculations.

Figure 2: Ratio mean wealth above $w$ divided by $w, w_{m} / w$, France

Linear scale

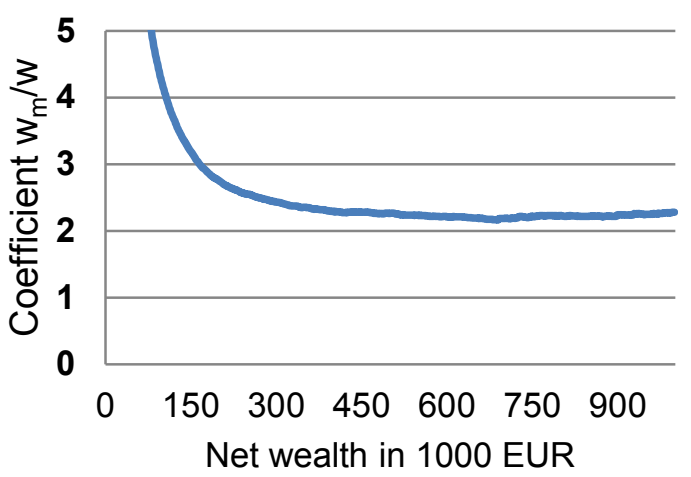

Lorithmic scale

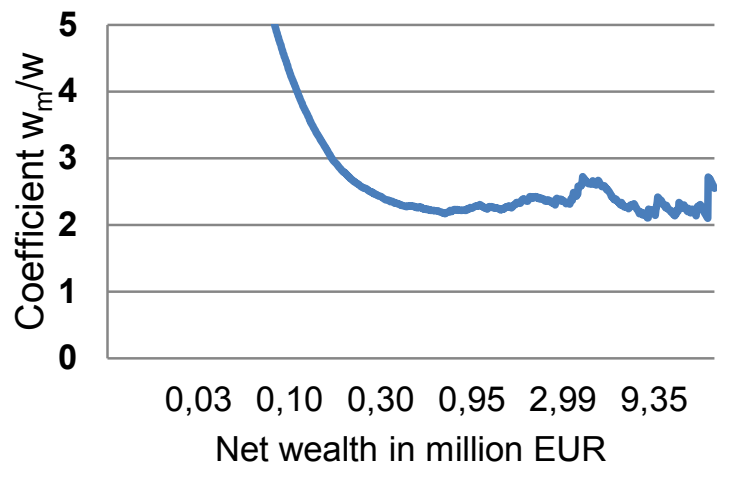

Source: HFCS, own calculations.

Figure 3: Ratio mean wealth above $w$ divided by $w, w_{m} / w$, Spain

Linear scale

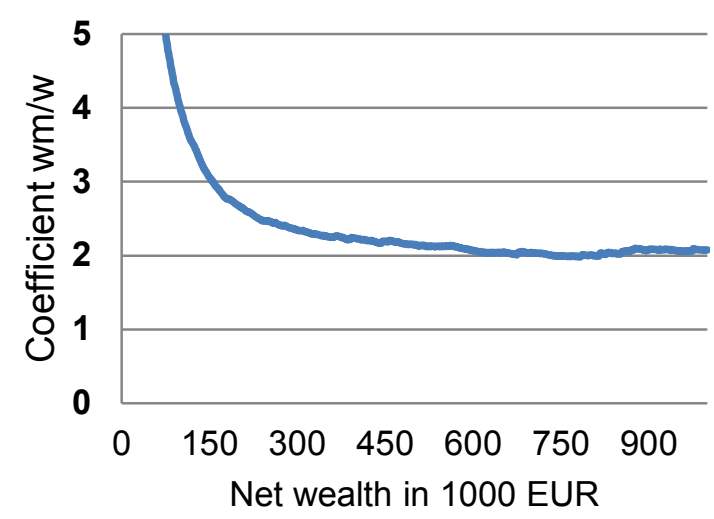

Logarithmic scale

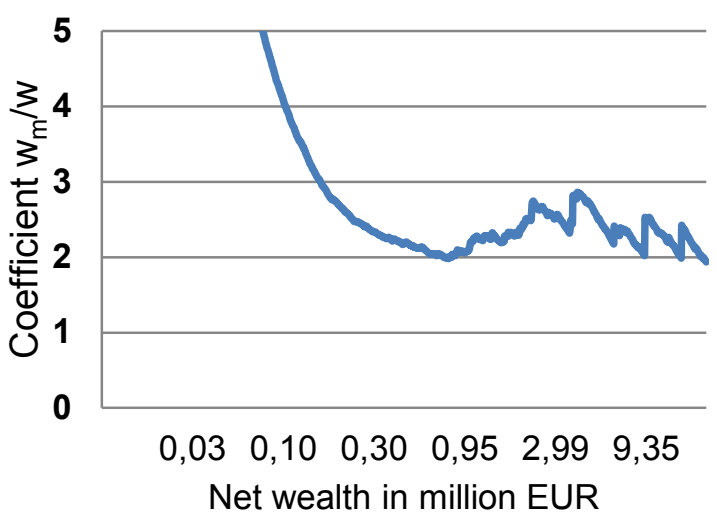

Source: HFCS, own calculations. 
Figure 4: Ratio mean wealth above $w$ divided by $w, w_{m} / w$, Greece
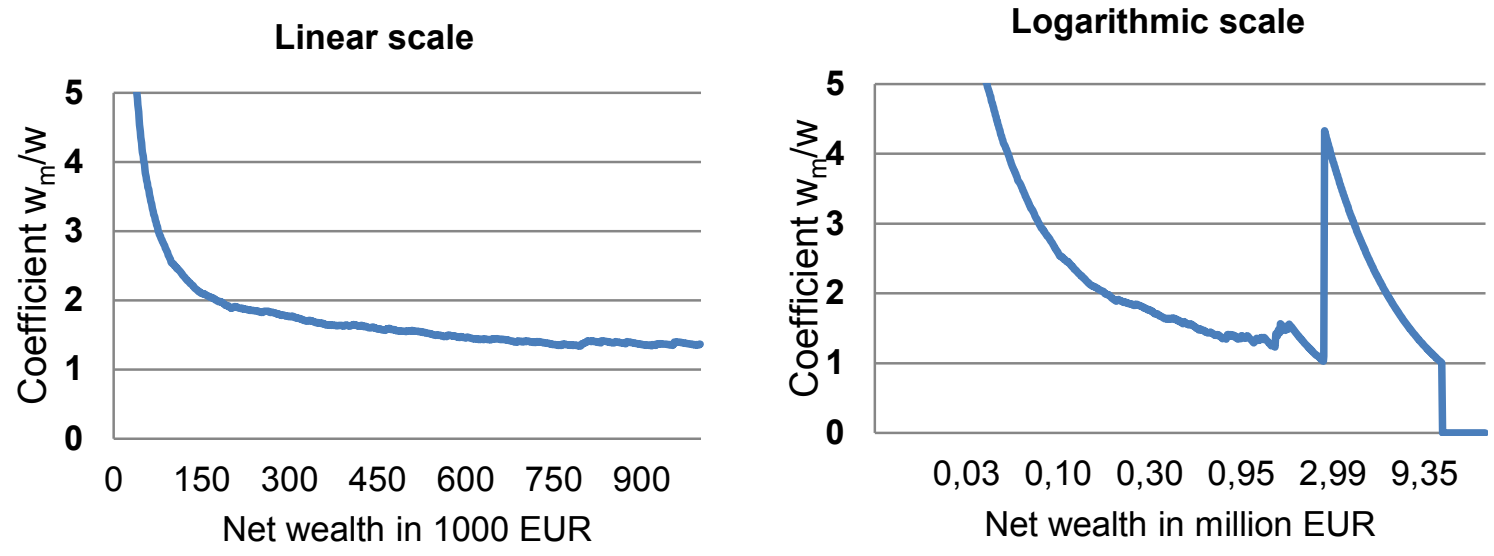

Source: HFCS, own calculations.

To choose the optimal combination of $w_{\min }$ and the rich list, we follow Vermeulen (2014) who experimented with $0.5,1$ and 2 million Euros as minimum wealth thresholds. For Germany and France we consider the top 300, top 200, top 100 and Forbes entries of the national rich lists. We neglect the lower ranks due to potential "heaping effects" (see above, section 2.2). We assume that each entry in the corresponding rich list represents a household. For Germany, we use the corrected list for households instead of "families" provided by the list, and remove households that are obviously living abroad. For the other countries we disregard these issues. Based on the formulas (5) and (7), we calculate the Pareto coefficient for these subsamples per country. Table 3 - Table 6 show the estimated coefficients by country and Figure 5 and Figure 6 illustrate them graphically for Germany and France.

Table 3: Estimated $\alpha$-coefficients for different subsamples, Germany

\begin{tabular}{|c|c|c|c|c|c|c|}
\hline \multirow{3}{*}{$\mathrm{W}_{\min }$} & \multirow{2}{*}{\multicolumn{2}{|c|}{ Excluding the rich list }} & \multicolumn{4}{|c|}{ Including the rich list } \\
\hline & & & \multirow{2}{*}{$\frac{\text { MM top300 }}{\alpha_{\text {Reg }}}$} & \multirow{2}{*}{$\frac{\text { MM top200 }}{\alpha_{\text {Reg }}}$} & \multirow{2}{*}{$\frac{\text { MM top100 }}{\alpha_{\text {Reg }}}$} & \multirow{2}{*}{$\begin{array}{c}\begin{array}{r}\text { Forbes } \\
\text { (top52) }\end{array} \\
\alpha_{\text {Reg }}\end{array}$} \\
\hline & $\alpha_{P M L}$ & $\alpha_{\text {Reg }}$ & & & & \\
\hline \multirow[t]{2}{*}{0.5 million Euro } & 1.597 & 1.535 & 1.374 & 1.370 & 1.378 & 1.408 \\
\hline & & $(0.042)$ & $(0.001)$ & $(0.001)$ & $(0.003)$ & $(0.005)$ \\
\hline \multirow[t]{2}{*}{1 million Euro } & 1.451 & 1.613 & 1.361 & 1.358 & 1.365 & 1.396 \\
\hline & & $(0.094)$ & $(0.002)$ & $(0.002)$ & $(0.003)$ & $(0.005)$ \\
\hline \multirow[t]{2}{*}{2 million Euro } & 1.342 & 1.767 & 1.342 & 1.340 & 1.347 & 1.379 \\
\hline & & $(0.186)$ & $(0.005)$ & $(0.005)$ & $(0.005)$ & $(0.006)$ \\
\hline
\end{tabular}

Source: HFCS, Forbes list, manager magazin list; own calculations. 
Table 4: Estimated $\alpha$-coefficients for different subsamples, France

\begin{tabular}{|c|c|c|c|c|c|c|}
\hline \multirow{3}{*}{$\mathrm{W}_{\min }$} & \multirow{2}{*}{\multicolumn{2}{|c|}{ Excluding the rich list }} & \multicolumn{4}{|c|}{ Including the rich list } \\
\hline & & & \multirow{2}{*}{$\begin{array}{c}\begin{array}{c}\text { Challenges } \\
\text { top300 }\end{array} \\
\alpha_{\text {Reg }}\end{array}$} & \multirow{2}{*}{$\begin{array}{c}\begin{array}{c}\text { Challenges } \\
\text { top200 }\end{array} \\
\alpha_{\text {Reg }}\end{array}$} & \multirow{2}{*}{$\begin{array}{c}\begin{array}{c}\text { Challenges } \\
\text { top100 }\end{array} \\
\alpha_{\text {Reg }}\end{array}$} & \multirow{2}{*}{$\begin{array}{c}\begin{array}{c}\text { Forbes } \\
\text { (top11) }\end{array} \\
\alpha_{\text {Reg }}\end{array}$} \\
\hline & $\alpha_{P M L}$ & $\alpha_{\text {Reg }}$ & & & & \\
\hline \multirow[t]{2}{*}{0.5 million Euro } & 1.783 & 1.819 & 1.569 & 1.545 & 1.534 & 1.722 \\
\hline & & $(0.006)$ & $(0.008)$ & $(0.008)$ & $(0.011)$ & $(0.026)$ \\
\hline \multirow[t]{2}{*}{1 million Euro } & 1.804 & 1.763 & 1.506 & 1.473 & 1.443 & 1.613 \\
\hline & & $(0.011)$ & $(0.008)$ & $(0.008)$ & $(0.009)$ & $(0.033)$ \\
\hline \multirow[t]{2}{*}{2 million Euro } & 1.689 & 1.650 & 1.437 & 1.403 & 1.362 & 1.487 \\
\hline & & $(0.019)$ & $(0.009)$ & $(0.008)$ & $(0.008)$ & $(0.033)$ \\
\hline
\end{tabular}

Source: HFCS, Forbes list, Challenges list; own calculations.

Table 5: Estimated $\alpha$-coefficients for different subsamples, Spain

\begin{tabular}{|c|c|c|c|c|}
\hline \multirow{3}{*}{$\mathrm{W}_{\min }$} & \multirow{2}{*}{\multicolumn{2}{|c|}{ Excluding the rich list }} & \multicolumn{2}{|c|}{ Including the rich list } \\
\hline & & & \multirow{2}{*}{$\begin{array}{c}\text { El mundo (top74) } \\
\alpha_{\text {Reg }}\end{array}$} & \multirow{2}{*}{$\begin{array}{c}\text { Forbes (top12) } \\
\alpha_{\text {Reg }} \\
\end{array}$} \\
\hline & $\alpha_{P M L}$ & $\alpha_{\text {Reg }}$ & & \\
\hline \multirow[t]{2}{*}{0.5 million euro } & 1.858 & 1.880 & 1.569 & 1.812 \\
\hline & & $(0.010)$ & $(0.013)$ & $(0.019)$ \\
\hline \multirow[t]{2}{*}{1 million euro } & 2.152 & 1.761 & 1.445 & 1.689 \\
\hline & & $(0.013)$ & $(0.010)$ & $(0.021)$ \\
\hline \multirow[t]{2}{*}{2 million euro } & 1.809 & 1.651 & 1.345 & 1.590 \\
\hline & & $(0.022)$ & $(0.006)$ & $(0.025)$ \\
\hline
\end{tabular}

Source: HFCS, Forbes list, Challenges list; own calculations. 
Table 6: Estimated $\alpha$-coefficients for different subsamples, Greece

\begin{tabular}{|c|c|c|c|c|}
\hline \multirow{3}{*}{$\mathrm{W}_{\min }$} & \multirow{2}{*}{\multicolumn{2}{|c|}{ Excluding the rich list }} & \multicolumn{2}{|c|}{ Including the rich list } \\
\hline & & & \multirow{2}{*}{$\begin{array}{c}\text { Greek Rich List } \\
\text { (top29) } \\
\alpha_{\text {Reg }}\end{array}$} & \multirow{2}{*}{$\begin{array}{c}\text { Forbes (top18) } \\
\alpha_{\text {Reg }}\end{array}$} \\
\hline & $\alpha_{\mathrm{PML}}$ & $\alpha_{\text {Reg }}$ & & \\
\hline \multirow[t]{2}{*}{0.5 million euro } & 2.638 & 3.117 & 1.720 & 1.220 \\
\hline & & $(0.071)$ & $(0.033)$ & $(0.017)$ \\
\hline \multirow[t]{2}{*}{1 million euro } & 3.761 & 3.190 & 1.476 & 1.018 \\
\hline & & $(0.139)$ & $(0.038)$ & $(0.021)$ \\
\hline \multirow[t]{2}{*}{2 million euro } & 11.378 & 3.069 & 1.083 & 0.738 \\
\hline & & $(0.345)$ & $(0.094)$ & $(0.091)$ \\
\hline
\end{tabular}

Source: HFCS, Forbes list, Challenges list; own calculations.

Comparing Table 3, Table 4 and Table 5, it becomes evident that the estimated $\alpha$-coefficients are larger in almost all subsamples in France and Spain than in Germany. This is a first indication for a stronger concentration in the German top tail wealth distribution, as lower values of $\alpha$ indicate a stronger wealth concentration at the top. ${ }^{5}$

Moreover, the inclusion of information from national rich lists substantially affects the estimates for $\alpha$, resulting in a lower value and hence higher inequality in all subsamples for Germany, France and Spain. In Germany, increasing $w_{\min }$ from 0.5 million to 2 million Euro does only slightly decrease the estimated alpha-coefficient for the specifications that include the rich list. Restricting the entries from the German rich list to the top 200 or top 100 households has almost no impact on the estimated alpha-coefficients. In France and Spain, an increase in $w_{\min }$ leads to a moderate reduction of the estimated alpha-coefficients. The estimates based on the rich lists indicate a significantly lower level of alpha-coefficients which means a higher concentration of top wealth. The inclusion of the national rich lists instead of the Forbes list substantially increases the top wealth concentration, especially for France and Spain. The Forbes list comprises only few observations for these countries, 11 for France and 12 for Spain.

5 Based on tabulated data from the French wealth tax assessment of 1995, Zucman (2008) estimates $\alpha$ coefficients of 1.7 to 2.0 depending on the wealth strata or cut-off point respectively. For Spain, we found similar estimations based on tax files. 
For Greece, the estimated $\alpha$-coefficients, based on the HFCS data, suggest a much less unequal distribution of wealth compared to the three other countries (Table 6). However, the data quality seems to be lower. With the HFCS there is a substantially lower oversampling probability of the rich in Greece (ECB, 2013a). The low number of households reporting a net wealth of one or two million Euro increases the imprecision of the estimates. Moreover, the rich lists for Greece include a small number of observations and seem to be less reliable. The data for Greece do not show clear concentration patterns (Table 6). Therefore, the results for Greece have to be considered with caution and should not be over interpreted.

Figure 5 and Figure 6 illustrate the tail wealth distribution for Germany and France, distinguished by the type of rich list and the three cut-off points $w_{\min }$ chosen. Following the literature we present the complementary cumulative distribution function (ccdf, equation (3)), both the empirical distribution and the estimated Pareto distribution. We present the tail distribution for the HFCS and the rich lists, where the first row augments the survey data with the top 300 richest households of the corresponding national rich lists, the second row with the top 200 richest households of the national rich lists, and the third row with the national entries at the Forbes World's Billionaires list. The first column shows the tail distribution for a lower bound for household wealth of 500 thousand Euros, the second for $w_{\min }$ of 1 million Euros, and the third column for $w_{\text {min }}$ of 2 million Euros. In addition, all graphs contain the estimated relationship on the log-log scale based on different samples (HFCS only and HFCS jointly with the rich list). 


\section{Figure 5: Tail wealth distribution by rich list and minimum wealth, Germany}

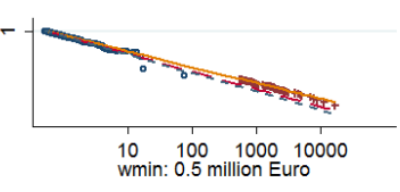

Mananger Magazin 200 richest $\mathrm{HH}$
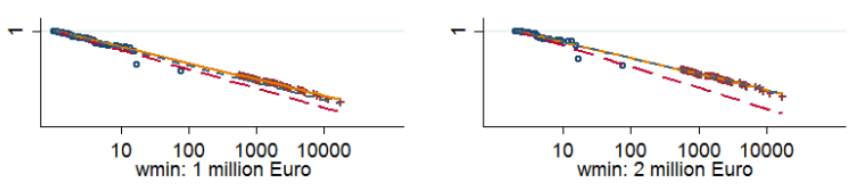

Manager Magazin 300 richest $\mathrm{HH}$
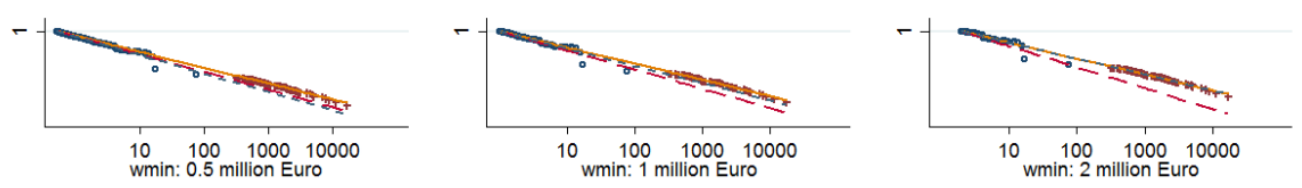

Forbes richest $\mathrm{HH}$
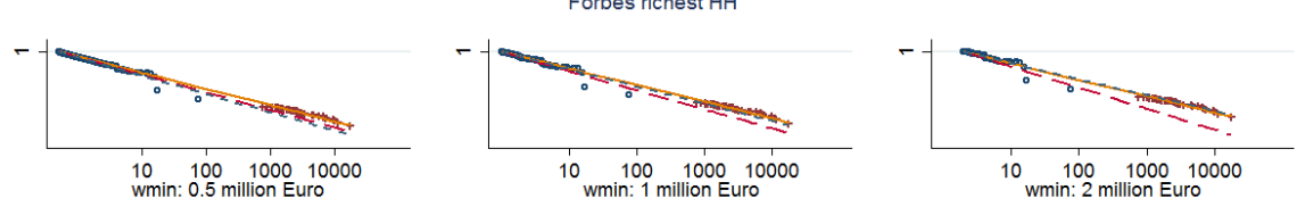

Source: HFCS, manager magazin list and Forbes list; own calculations. Note: Wealth in million Euros.

\section{Figure 6: Tail wealth distribution by rich list and minimum wealth, France}
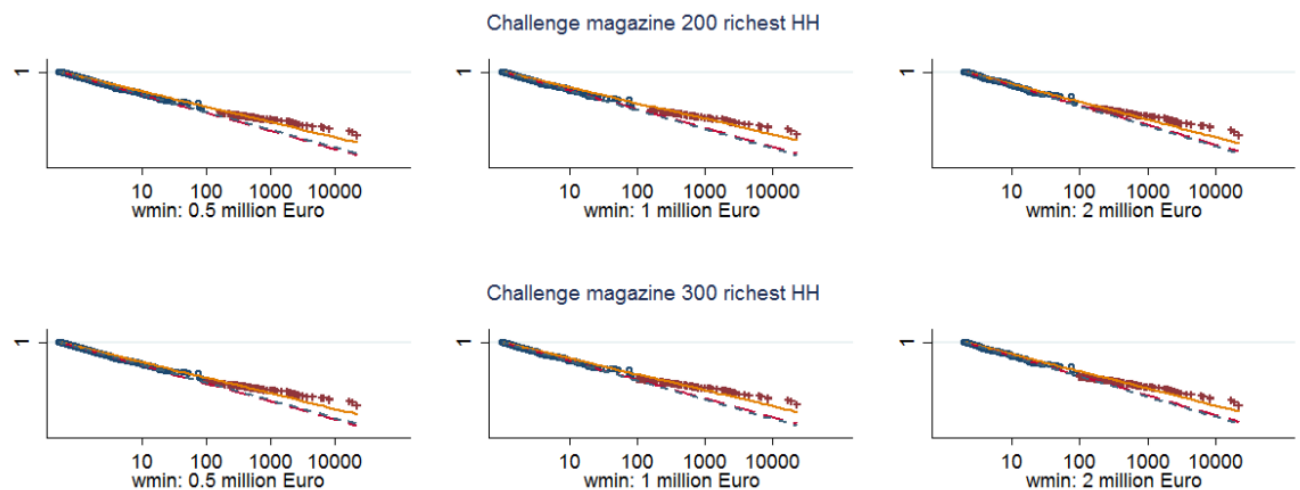

Challenge magazine 300 richest $\mathrm{HH}$
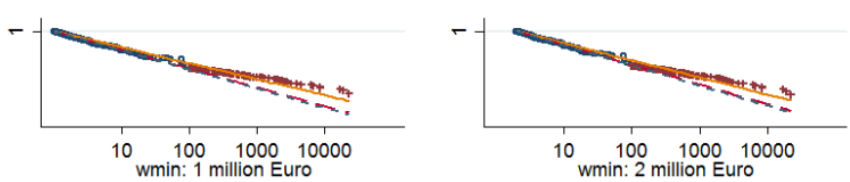

Forbes magazine
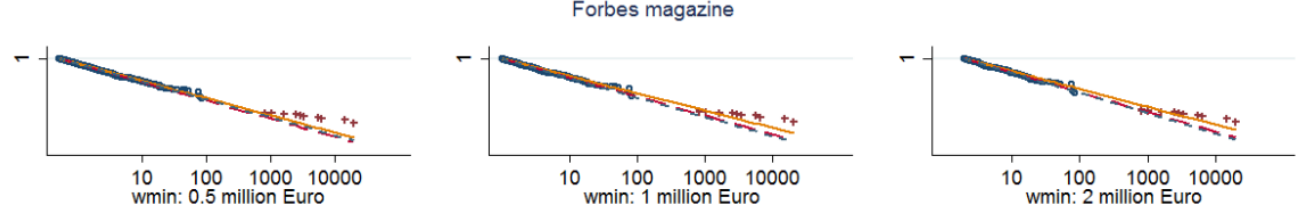

\begin{tabular}{|c|c|c|}
\hline $\begin{array}{cl}\circ & \text { HFCS } \\
- & - \text { Regression (HFCS) }\end{array}$ & $\begin{array}{l}\text { + Challenge magazine/ Forbes } \\
\text { - - - Pseudo-ML (HFCS) }\end{array}$ & —— Regression(HFCS and rich list) \\
\hline
\end{tabular}

Source: HFCS, Challenges list and Forbes list; own calculations. Note: Wealth in million Euros. 
By comparing the plots for the top 300, top 200, and the Forbes rich list, we observe that the top 200 provides a good fit to the Pareto lines for Germany and France, including HFCS and the national rich list. Therefore, we choose the top 200 households of the corresponding rich lists for Germany and France as baseline specification. Including more households from the national rich list would increase the risk of the "heaping effect" and the wealth information becomes less reliable. At the same time, we aim to use as much information from the rich list as possible and therefore prefer the top 200 over the top 100 rich list. For Spain and Greece, we rely on the entire national rich list.

\subsection{Imputation of the missing rich households}

This section describes the imputation of the missing rich households. For Germany, Figure 5 shows a large gap between the richest household in the HFCS and the poorest household in the corresponding rich lists. In France, this gap is substantially smaller as illustrated by Figure 6 , reflecting the better representation of wealthy households in the French part of the survey. This is also the case for Spain. The aim of the imputation is to create households that are representative for this gap.

Furthermore, Figure 5 and Figure 6 show that HFCS observations with high wealth tend to deviate more strongly from the Pareto line, in particular for Germany. Obviously, high levels of household wealth are more prone to sampling error and selectivity due to non-response. Therefore, we decided to cut off all households in the HFCS that exceed the threshold of 3 million Euros (Germany, France and Spain) and 1 million Euros (Greece) respectively. Next, we calculate the complementary cumulative distribution function (ccdf) of the Pareto distribution, based on the chosen parameters with $w_{\min }$ of 500 thousand Euros and $\alpha$ of 1.37 for Germany, 1.55 for France, 1.57 for Spain, and 1.22 for Greece, Table 3 - Table 6. The imputed households were weighted such that they match the total sum of household weights in the HFCS with wealth higher than the mentioned threshold. We restrict the range of imputed households to values from this threshold to the poorest household from the national rich list. ${ }^{6}$ The joint tail wealth distributions for the four countries are plotted by Figure 7 - Figure 10. Note that the steeper the Pareto line the lower is the wealth concentration.

6 In Germany and Spain, we impute households in the range of three to 500 million Euros net wealth. In France, households are imputed in the range of three to 300 million Euros of net wealth. The imputed households in Greece own net wealth between one million and 100 million Euros. 


\section{Figure 7: Adjusted tail wealth distribution, Germany}

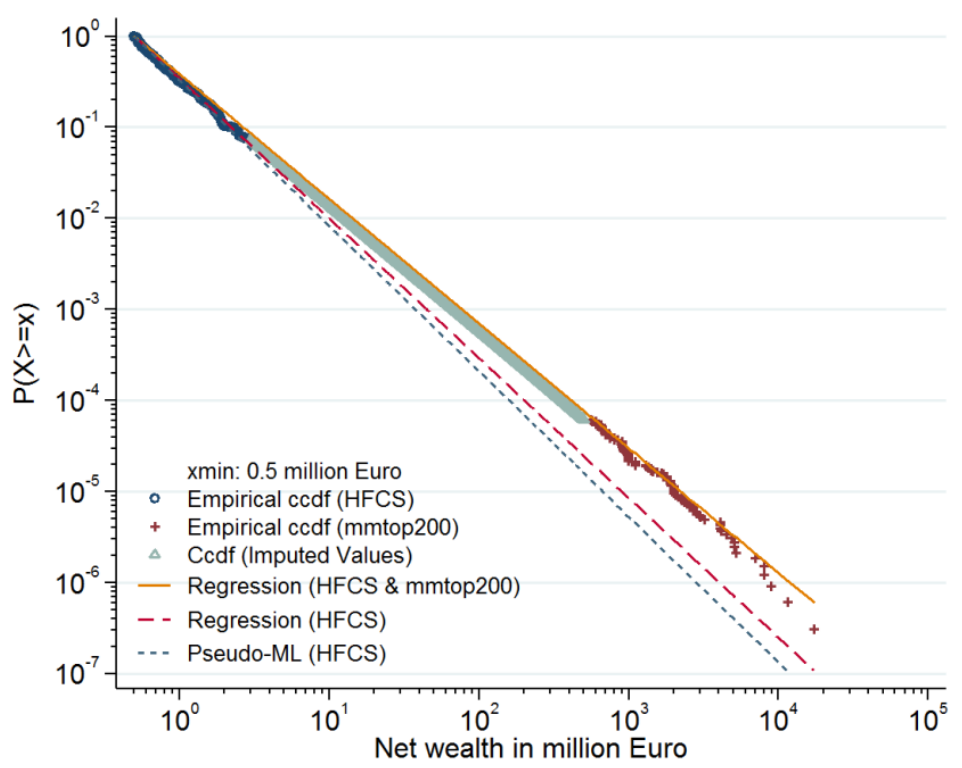

Source: HFCS, manager magazin; own calculations.

\section{Figure 8: Adjusted tail wealth distribution, France}

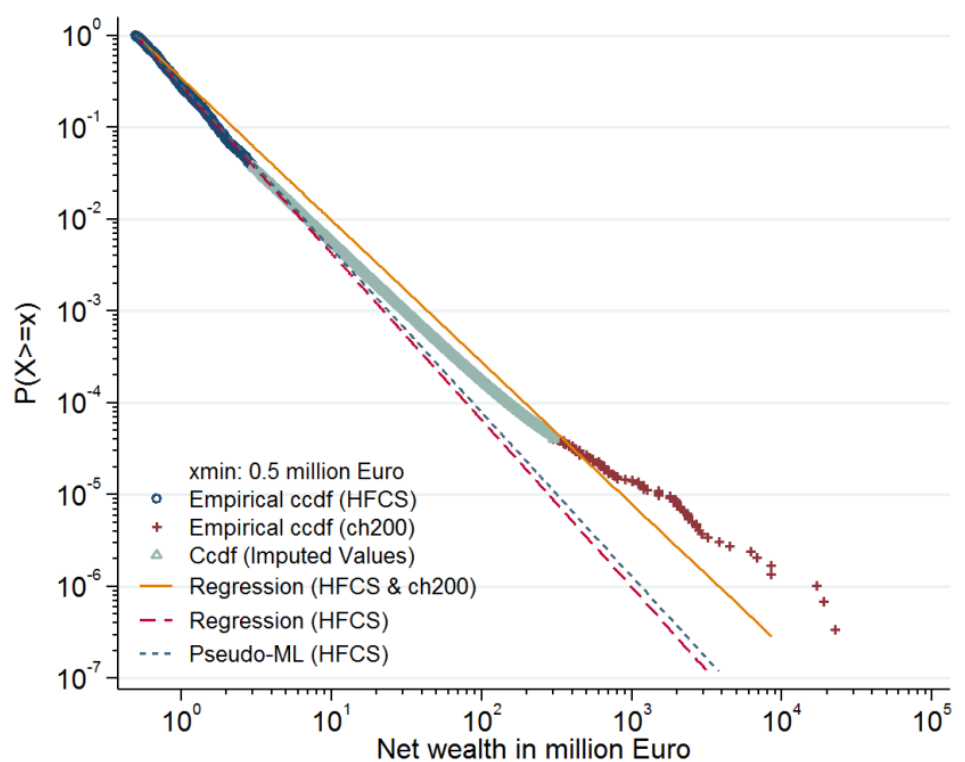

Source: HFCS, Challenges magazine; own calculations. 


\section{Figure 9: Adjusted tail wealth distribution, Spain}

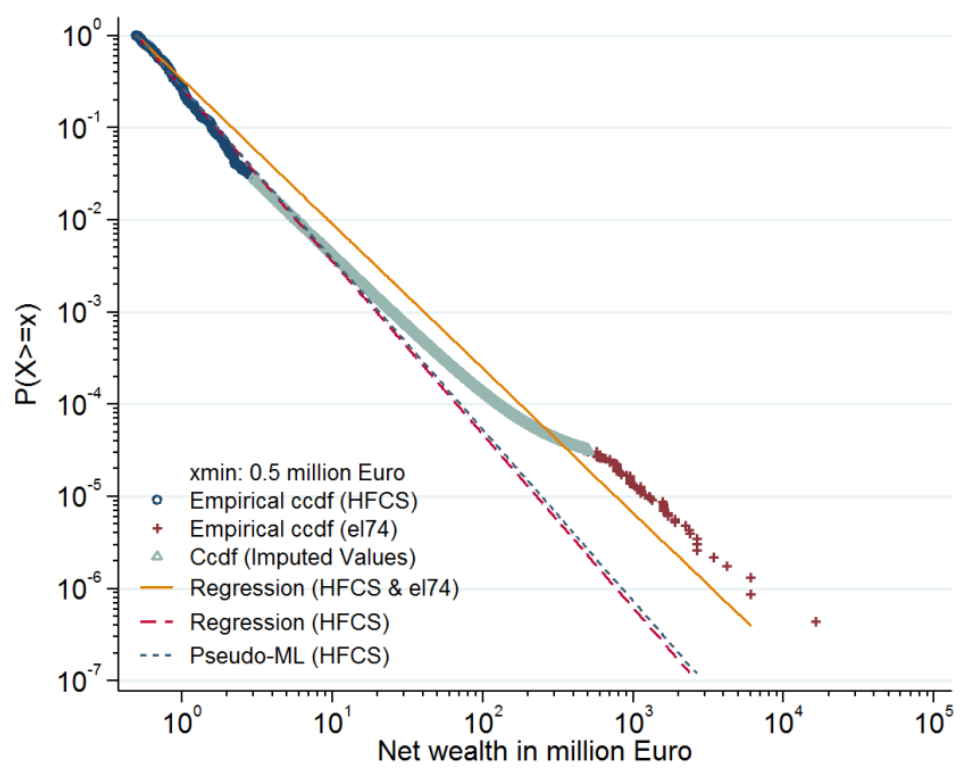

Source: HFCS, El mundo magazine; own calculations.

\section{Figure 10: Adjusted tail wealth distribution, Greece}

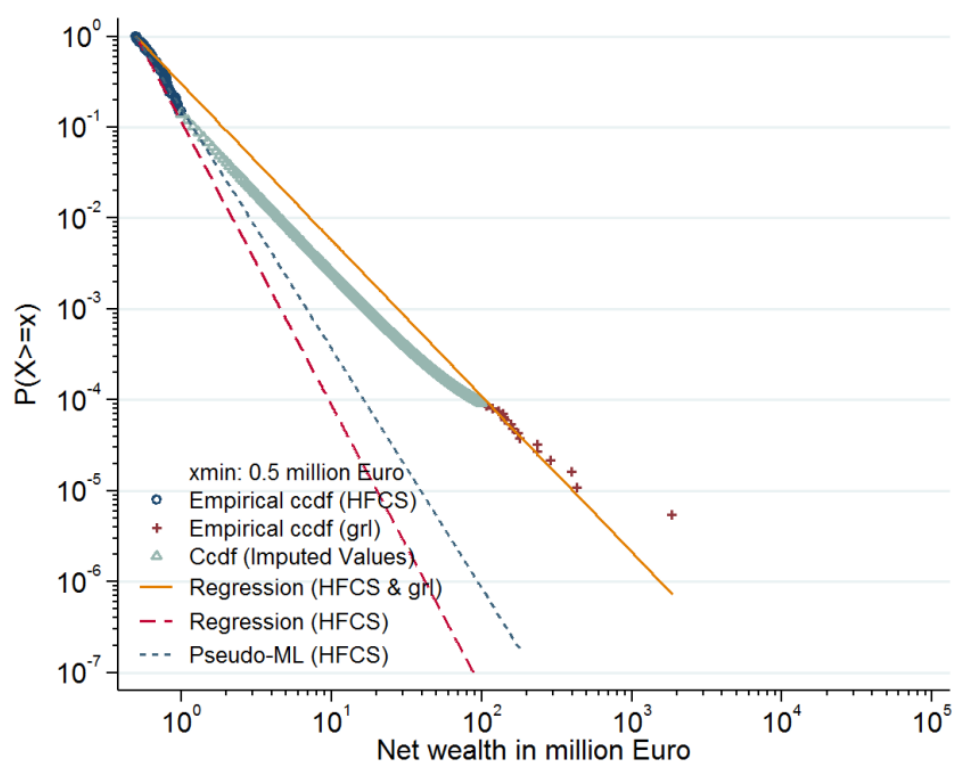

Source: HFCS, Greek Rich List; own calculations.

\section{Results: Impact of correcting for the missing top wealth on the wealth distribution}

Based on the integrated data sets, which contain the households from the HFCS, from the imputation, and from the corresponding national rich lists we analyze the impact of correcting for the missing rich on the wealth distribution. 
Table 7 shows the German household net wealth distribution before and after top wealth imputation. The left part covers the distribution that is based only on the HFCS, while the right part shows the adjusted household net wealth distribution, consisting of the HFCS, the imputed cases and households from the manager magazin. The lower section provides summary inequality measures of household net wealth. Focusing on the left part, the household net wealth distribution exhibits a large concentration of wealth in the top decile. While the poorest 50 percent of all households in Germany hold less than 3 percent of total net wealth, the share of the richest 10 percent hikes to almost 60 percent. Among them, the richest 1 percent of all households owns about 24 percent of total wealth, based solely on the HFCS data. After adjusting the net wealth distribution for the missing rich, the total household net wealth increases by 1,000 billion Euros to 8,755 billion Euros (+13 percent). The adjustment substantially affects the wealth concentration. The share of household net wealth, held by the top decile, increases by 5 percentage points to 64 percent, while the share of the richest 1 percent climbs up by 9 percentage points to 33 percent. The wealth share of the top 0.1 percent increases most strongly from 4 percent to 17 percent since the imputation mainly affects this wealth quantile. 
Table 7: Distribution of household net wealth in Germany

\begin{tabular}{|c|c|c|c|c|c|c|}
\hline \multirow{3}{*}{$\begin{array}{c}\text { Fractiles } \\
\text { household net } \\
\text { wealth }\end{array}$} & \multicolumn{3}{|c|}{ Database HFCS } & \multicolumn{3}{|c|}{$\begin{array}{l}\text { Database HFCS including } \\
\text { imputed top wealth distribution }\end{array}$} \\
\hline & \multirow{2}{*}{$\begin{array}{l}\text { Percentile } \\
1000 \text { Euro }\end{array}$} & \multicolumn{2}{|c|}{ Total } & \multirow{2}{*}{\begin{tabular}{|l|} 
Percentile \\
1000 Euro
\end{tabular}} & \multicolumn{2}{|c|}{ Total } \\
\hline & & bill. Euro & $\%$ & & bill. Euro & $\%$ \\
\hline $1^{\text {st }}-5^{\text {th }}$ decile & 1 & 222 & 2.9 & 1 & 222 & 2.5 \\
\hline $6^{\text {th }}$ decile & 52 & 294 & 3.8 & 52 & 294 & 3.4 \\
\hline $7^{\mathrm{h}}$ decile & 99 & 501 & 6.5 & 99 & 501 & 5.7 \\
\hline $8^{\text {th }}$ decile & 165 & 847 & 10.9 & 165 & 847 & 9.7 \\
\hline $9^{\text {th }}$ decile & 262 & 1313 & 17.0 & 262 & 1313 & 15.0 \\
\hline $10^{\text {th }}$ decile & 438 & 4567 & 59.0 & 438 & 5578 & 63.7 \\
\hline Total & 1 & 7743 & 100.0 & 1 & 8755 & 100.0 \\
\hline Top 7,5\% & 525 & 4061 & 52.5 & 525 & 5073 & 57.9 \\
\hline Top 5\% & 668 & 3517 & 45.4 & 668 & 4529 & 51.7 \\
\hline Top 2,5\% & 1063 & 2694 & 34.8 & 1063 & 3705 & 42.3 \\
\hline Top 1\% & 1887 & 1847 & 23.9 & 1887 & 2859 & 32.7 \\
\hline Top $0,5 \%$ & 3317 & 1363 & 17.6 & 3400 & 2369 & 27.1 \\
\hline Top 0,1\% & 13581 & 306 & 3.9 & 10900 & 1516 & 17.3 \\
\hline \multicolumn{7}{|c|}{ Summary inequality measures of household net wealth } \\
\hline Gini coefficient & \multirow{2}{*}{\multicolumn{3}{|c|}{0.7461}} & \multicolumn{3}{|c|}{0.7751} \\
\hline Entropy meas. ${ }^{1)}$ & & & & & & \\
\hline $\mathrm{GE}(1)$ & \multicolumn{3}{|c|}{1.2894} & \multicolumn{3}{|c|}{1.8493} \\
\hline $\mathrm{GE}(2)$ & \multicolumn{3}{|c|}{5.5693} & \multicolumn{3}{|c|}{326.84} \\
\hline
\end{tabular}

Source: HFCS, 2011, own calculations.

The considerable increase in wealth concentration due to the adjustment of the household net wealth distribution is also reflected in the standard inequality measures. The Gini coefficient which is relatively sensitive to changes in the middle of the distribution increases from 0.75 to 0.78. In the calculation of the Gini coefficient, we set negative or zero net wealth to one Euro, however smaller positive values do not affect the results. ${ }^{7}$ The GE(2) measure, which strongly responds to changes at the top of the distribution, skyrockets.

7 In Germany, the share of households holding zero or negative net wealth is 6.2 percent (in France: 2.6 percent, Spain: 2.4 percent, Greece: 6.5 percent). 
Table 8: Distribution of household net wealth in France

\begin{tabular}{|c|c|c|c|c|c|c|}
\hline \multirow{3}{*}{$\begin{array}{c}\text { Fractiles } \\
\text { household net } \\
\text { wealth }\end{array}$} & \multicolumn{3}{|c|}{ Database HFCS } & \multicolumn{3}{|c|}{$\begin{array}{l}\text { Database HFCS including } \\
\text { imputed top wealth distribution }\end{array}$} \\
\hline & \multirow{2}{*}{$\begin{array}{l}\text { Percentile } \\
1000 \text { Euro }\end{array}$} & \multicolumn{2}{|c|}{ Total } & \multirow{2}{*}{\begin{tabular}{|l|} 
Percentile \\
1000 Euro
\end{tabular}} & \multicolumn{2}{|c|}{ Total } \\
\hline & & bill. Euro & $\%$ & & bill. Euro & $\%$ \\
\hline $1^{\text {st }}-5^{\text {th }}$ decile & 1 & 359 & 5.5 & 1 & 359 & 5.3 \\
\hline $6^{\text {th }}$ decile & 118 & 411 & 6.3 & 118 & 411 & 6.1 \\
\hline $7^{\mathrm{h}}$ decile & 177 & 578 & 8.9 & 177 & 578 & 8.5 \\
\hline $8^{\text {th }}$ decile & 240 & 781 & 12.0 & 240 & 781 & 11.5 \\
\hline $9^{\text {th }}$ decile & 331 & 1139 & 17.5 & 331 & 1139 & 16.8 \\
\hline $10^{\text {th }}$ decile & 517 & 3235 & 49.7 & 517 & 3499 & 51.7 \\
\hline Total & 1 & 6503 & 100.0 & 1 & 6767 & 100.0 \\
\hline Top 7,5\% & 615 & 2843 & 43.7 & 615 & 3107 & 45.9 \\
\hline Top 5\% & 762 & 2363 & 36.3 & 762 & 2627 & 38.8 \\
\hline Top 2,5\% & 1096 & 1736 & 26.7 & 1096 & 2000 & 29.6 \\
\hline Top 1\% & 1779 & 1159 & 17.8 & 1779 & 1423 & 21.0 \\
\hline Top $0,5 \%$ & 2676 & 866 & 13.3 & 2676 & 1130 & 16.7 \\
\hline Top $0,1 \%$ & 7010 & 448 & 6.9 & 7200 & 692 & 10.2 \\
\hline \multicolumn{7}{|c|}{ Summary inequality measures of household net wealth } \\
\hline Gini coefficient & \multirow{2}{*}{\multicolumn{3}{|c|}{0.6730}} & \multirow{2}{*}{\multicolumn{3}{|c|}{0.6857}} \\
\hline Entropy meas. ${ }^{1)}$ & & & & & & \\
\hline $\mathrm{GE}(1)$ & \multicolumn{3}{|c|}{1.0107} & \multicolumn{3}{|c|}{1.2694} \\
\hline $\mathrm{GE}(2)$ & \multicolumn{3}{|c|}{5.9386} & \multicolumn{3}{|c|}{485.76} \\
\hline
\end{tabular}

Source: HFCS, 2011, own calculations.

Table 8 and Table 9 provide the corresponding French and Spanish household net wealth distribution. ${ }^{8}$ Again, the left part covers the distribution that is based only on the HFCS, while the right part shows the adjusted household net wealth distribution, consisting of the HFCS, the imputed cases from the Challenges (France) or El mundo (Spain) rich lists. Both countries show a substantial wealth concentration, however somewhat smaller than in Germany. While households below the median hold 5.5 percent in France and 13.1 percent in Spain, the corresponding shares of the top decile are about 50 percent (3,200 billion Euros) and 43 percent (2,100 billion Euros). The richest 1 percent of all households owns about 18 percent in France

8 Azpitarte (2010) analyzes the Spanish household net wealth distribution based on the Spanish Survey of Household Finances (EFF) 2002. 
and about 15 percent in Spain of total net wealth. This is substantially lower than the corresponding share in Germany (24 percent).

Table 9: Distribution of household net wealth in Spain

\begin{tabular}{|c|c|c|c|c|c|c|}
\hline \multirow{3}{*}{$\begin{array}{c}\text { Fractiles } \\
\text { household net } \\
\text { wealth }\end{array}$} & \multicolumn{3}{|c|}{ Database HFCS } & \multicolumn{3}{|c|}{$\begin{array}{l}\text { Database HFCS including } \\
\text { imputed top wealth distribution }\end{array}$} \\
\hline & \multirow{2}{*}{$\begin{array}{l}\text { Percentile } \\
1000 \text { Euro }\end{array}$} & \multicolumn{2}{|c|}{ Total } & \multirow{2}{*}{\begin{tabular}{|l|} 
Percentile \\
1000 Euro
\end{tabular}} & \multicolumn{2}{|c|}{ Total } \\
\hline & & bill. Euro & $\%$ & & bill. Euro & $\%$ \\
\hline $1^{\text {st }}-5^{\text {th }}$ decile & 1 & 647 & 13.1 & 1 & 647 & 12.8 \\
\hline $6^{\text {th }}$ decile & 183 & 350 & 7.1 & 183 & 350 & 6.9 \\
\hline $7^{\mathrm{h}}$ decile & 232 & 440 & 8.9 & 232 & 440 & 8.7 \\
\hline $8^{\text {th }}$ decile & 291 & 574 & 11.6 & 291 & 574 & 11.3 \\
\hline $9^{\text {th }}$ decile & 391 & 808 & 16.3 & 391 & 808 & 15.9 \\
\hline $10^{\text {th }}$ decile & 614 & 2138 & 43.1 & 614 & 2252 & 44.4 \\
\hline Total & 1 & 4958 & 100.0 & 1 & 5071 & 100.0 \\
\hline Top 7,5\% & 717 & 1856 & 37.4 & 717 & 1969 & 38.8 \\
\hline Top 5\% & 867 & 1516 & 30.6 & 867 & 1629 & 32.1 \\
\hline Top 2,5\% & 1152 & 1096 & 22.1 & 1152 & 1209 & 23.8 \\
\hline Top 1\% & 1862 & 734 & 14.8 & 1862 & 847 & 16.7 \\
\hline Top $0,5 \%$ & 2501 & 556 & 11.2 & 2501 & 669 & 13.2 \\
\hline Top 0,1\% & 7374 & 291 & 5.9 & 7000 & 408 & 8.0 \\
\hline \multicolumn{7}{|c|}{ Summary inequality measures of household net wealth } \\
\hline Gini coefficient & \multirow{2}{*}{\multicolumn{3}{|c|}{0.5723}} & \multirow{2}{*}{\multicolumn{3}{|c|}{0.5818}} \\
\hline Entropy meas. ${ }^{1)}$ & & & & & & \\
\hline $\mathrm{GE}(1)$ & \multicolumn{3}{|c|}{0.7468} & \multicolumn{3}{|c|}{0.9038} \\
\hline $\mathrm{GE}(2)$ & \multicolumn{3}{|c|}{8.0614} & \multicolumn{3}{|c|}{161.23} \\
\hline
\end{tabular}

Source: HFCS, 2011, own calculations.

Adjusting the French household net wealth distribution for the missing rich increases total wealth only moderately, compared to Germany, by 270 ( +4 percent) to 6,770 billion Euros. Accordingly, the share of total net wealth held by the top 1 percent increases by 3 percentage points to 21 percent of total household net wealth. In Spain, the adjustment of the household net wealth distribution for the missing rich is even smaller. Total net wealth increases by 113 (+2 percent) to 5,070 billion Euros, the wealth share of the top 1 percent increases by 2 percentage points. In comparison to Germany, these increases in wealth concentration due to adjusting for the missing rich are substantially smaller. The Gini coefficient for France increases from 0.67 to 0.69 and for Spain from 0.57 to 0.58 , reflecting a substantially lower inequality than in Germany. 
Table 10: Distribution of household net wealth in Greece

\begin{tabular}{|c|c|c|c|c|c|c|}
\hline \multirow{3}{*}{$\begin{array}{c}\text { Fractiles } \\
\text { household net } \\
\text { wealth }\end{array}$} & \multicolumn{3}{|c|}{ Database HFCS } & \multicolumn{3}{|c|}{$\begin{array}{l}\text { Database HFCS including } \\
\text { imputed top wealth distribution }\end{array}$} \\
\hline & \multirow{2}{*}{$\begin{array}{l}\text { Percentile } \\
1000 \text { Euro }\end{array}$} & \multicolumn{2}{|c|}{ Total } & \multirow{2}{*}{\begin{tabular}{|l|} 
Percentile \\
1000 Euro \\
\end{tabular}} & \multicolumn{2}{|c|}{ Total } \\
\hline & & bill. Euro & $\%$ & & bill. Euro & $\%$ \\
\hline $1^{\text {st }}-5^{\text {th }}$ decile & 1 & 77 & 12.6 & 1 & 77 & 12.1 \\
\hline $6^{\text {th }}$ decile & 103 & 47 & 7.8 & 103 & 47 & 7.4 \\
\hline $7^{\mathrm{h}}$ decile & 130 & 61 & 10.1 & 130 & 61 & 9.7 \\
\hline $8^{\text {th }}$ decile & 168 & 81 & 13.3 & 168 & 81 & 12.7 \\
\hline $9^{\text {th }}$ decile & 222 & 109 & 17.9 & 222 & 109 & 17.2 \\
\hline $10^{\text {th }}$ decile & 333 & 233 & 38.3 & 333 & 260 & 40.9 \\
\hline Total & 1 & 608 & 100.0 & 1 & 634 & 100.0 \\
\hline Top 7,5\% & 388 & 196 & 32.3 & 388 & 223 & 35.1 \\
\hline Top 5\% & 469 & 153 & 25.1 & 469 & 179 & 28.2 \\
\hline Top 2,5\% & 648 & 96 & 15.8 & 648 & 123 & 19.3 \\
\hline Top 1\% & 875 & 48 & 7.9 & 875 & 74 & 11.7 \\
\hline Top $0,5 \%$ & 1121 & 30 & 4.9 & 1100 & 55 & 8.6 \\
\hline Top $0,1 \%$ & 1510 & 8 & 1.4 & 2800 & 30 & 4.7 \\
\hline \multicolumn{7}{|c|}{ Summary inequality measures of household net wealth } \\
\hline Gini coefficient & \multirow{2}{*}{\multicolumn{3}{|c|}{0.5540}} & \multirow{2}{*}{\multicolumn{3}{|c|}{0.5726}} \\
\hline Entropy meas. ${ }^{1)}$ & & & & & & \\
\hline $\mathrm{GE}(1)$ & \multicolumn{3}{|c|}{0.5625} & \multicolumn{3}{|c|}{0.7094} \\
\hline $\mathrm{GE}(2)$ & \multicolumn{3}{|c|}{0.7845} & \multicolumn{3}{|c|}{23.40} \\
\hline
\end{tabular}

Source: HFCS, 2011, own calculations.

Finally, we focus on the distribution of Greek household net wealth, shown in Table 10. Again, while the left part of the table shows the wealth distribution originating from the HFCS data, the right part contains the adjusted net wealth distribution that consists of the HFCS data, imputed households, and households from the Greek Rich List. When focusing on the left part, it becomes evident that net wealth is less concentrated in the top decile of Greek households, compared to the other countries. While households below the median hold about $12 \%$ of total net wealth, the richest $10 \%$ of all households hold about $38 \%$ of total net wealth. The richest 1 percent ( 0.1 percent) holds about 8 percent (1.4 percent) of total net wealth. After the imputation of the missing rich households, total wealth increases moderately by 26 ( +4 percent) to 634 billion Euros. The imputation increases the share of net wealth that is held by the top 1 percent to almost 12 percent ( +3.8 percentage points). Compared to the impact of the imputation on the German household net wealth distribution, this increase is small. 
Next, we discuss the robustness of our results. Table 11 reports the share of net wealth, which is held by the top, in the four countries when the tail is replaced by synthetic and rich list households for different values of $w_{\min }$. The upper panel reports the share of net wealth, held by the top 5 percent, the middle panel the share held by the top 1 percent and the lower panel the share held by the top 0.1 percent. The data column reports the share that is calculated based on the original HFCS data, when the tail is not replaced. The section "excluding rich lists" calculates the share when the tail is replaced by the synthetic households that result from the $\alpha$-estimation that relies only on the HFCS data. The two remaining sections calculate the corresponding shares based on the $\alpha$-estimations that rely on information from the national rich lists or the Forbes list respectively.

Table 11: Share of net wealth held by the top when tail is replaced by the synthetic household and by rich list entries by various $w_{\text {min }}$

\begin{tabular}{|c|c|c|c|c|c|c|c|c|c|c|}
\hline & \multirow[b]{2}{*}{ Data } & \multicolumn{3}{|c|}{ Excluding rich lists } & \multicolumn{3}{|c|}{ National rich list } & \multicolumn{3}{|c|}{ Forbes } \\
\hline & & $>0.5 \mathrm{~m}$ & $>1 \mathrm{~m}$ & $>2 m$ & $>0.5 \mathrm{~m}$ & $>1 \mathrm{~m}$ & $>2 m$ & $>0.5 \mathrm{~m}$ & $>1 \mathrm{~m}$ & $>2 m$ \\
\hline \multicolumn{11}{|c|}{ Share of net wealth hold by the top $5 \%$} \\
\hline Germany & 45.4 & 48.7 & 47.7 & 46.2 & 51.7 & 51.9 & 52.1 & 50.8 & 50.9 & 52.4 \\
\hline France & 36.3 & 31.0 & 31.1 & 31.5 & 38.8 & 39.3 & 39.8 & 36.7 & 37.4 & 38.7 \\
\hline Spain & 30.6 & 26.0 & 26.2 & 26.5 & 32.1 & 32.9 & 33.7 & 29.9 & 30.4 & 32.8 \\
\hline Greece & 25.1 & 22.1 & 22.1 & 23.8 & 28.2 & 29.5 & 40.5 & 36.2 & 40.1 & 38.6 \\
\hline \multicolumn{11}{|c|}{ Share of net wealth hold by the top $1 \%$} \\
\hline Germany & 23.9 & 28.4 & 27.0 & 24.9 & 32.7 & 32.9 & 33.2 & 31.3 & 31.5 & 33.6 \\
\hline France & 17.8 & 12.5 & 12.7 & 13.2 & 21.0 & 21.6 & 22.3 & 18.3 & 19.1 & 20.9 \\
\hline Spain & 14.8 & 9.6 & 9.8 & 10.1 & 16.7 & 17.7 & 18.7 & 13.9 & 14.6 & 17.5 \\
\hline Greece & 7.9 & 6.4 & 6.3 & 8.4 & 11.7 & 13.3 & 26.8 & 21.5 & 26.3 & 24.4 \\
\hline \multicolumn{11}{|c|}{ Share of net wealth hold by the top $0.1 \%$} \\
\hline Germany & 3.9 & 12.8 & 11.4 & 9.4 & 17.3 & 17.6 & 17.9 & 15.8 & 16.1 & 18.1 \\
\hline France & 6.9 & 3.8 & 4.0 & 4.4 & 10.2 & 10.8 & 11.4 & 7.3 & 8.2 & 9.9 \\
\hline Spain & 5.9 & 2.7 & 3.0 & 3.2 & 8.0 & 9.0 & 9.9 & 5.2 & 5.8 & 8.6 \\
\hline Greece & 1.4 & 1.0 & 1.0 & 2.3 & 4.7 & 6.0 & 13.9 & 14.3 & 18.7 & 17.0 \\
\hline
\end{tabular}

Source: HFCS, 2011, National rich lists, own calculations. 
The results show that including external information from the national rich lists or the Forbes list increases the shares in all four countries. In Germany, France, and Spain the choice of $w_{\min }$ has only a minor impact on the calculated shares. However, for Greece the shares partly change substantially when we increase $w_{\min }$. To some extent this is due to the lower number of very wealthy households in the Greek HFCS data. In sum, the results for Germany, France and Spain are relatively robust to the choice of $w_{\min }$. In contrast, the results for Greece are not robust to the choice of $w_{\text {min }}$ and should be interpreted with caution. Further, our results indicate that using the national lists instead of Forbes significantly increase the top wealth shares, in particular for the top 1 percent and for the top 0,1 percent. This impact of national rich lists is higher for France and Spain than in Germany.

Finally, as a check for the corrected wealth distribution we compare our results with macroeconomic wealth data for the household sector from the national and financial accounts statistics (see Table A1 - A4 in the Appendix). Based on the detailed items provided for Germany we calculate a corrected net wealth aggregate by deducting items that are not recorded in the HFCS database, i.e. the value of occupational pension commitments and claims on private health insurance schemes. The available accounts for France are less detailed, so we roughly correct net wealth by deducting 50 percent of insurance technical reserves. For Spain we use the figures from national and financial accounts without any corrections. For Greece there is only available households' financial net wealth from the financial accounts.

In the case of Germany, the corrected households' net wealth aggregate reported in national and financial accounts statistics of 8,950 billion Euros (2010) slightly exceeds our estimation for total personal net wealth of 8,755 billion Euros (including imputed top wealth). In contrast, the personal net wealth aggregate for France reported in national and financial accounts is much higher than our estimate (9,470 billion Euros compared to 6,770 billion Euros). However, non-profit institutions serving households (NPISHs) are included in the French accounts, which might explain a minor part of the difference. Likewise, in Spain the households' net wealth aggregate in macroeconomic statistics of 6,650 billion Euros considerably exceeds our estimate of 5,070 billion Euros. For Greece, financial net wealth of households from financial account is reported to only 160 billion Euros. Our estimates for total net wealth result in 630 billion Euros, which mainly stems from real estate.

The remarkable underestimation of household net wealth in France and Spain compared to the respective aggregates from national and financial accounts might suggest a remaining underrepresentation inherent in our estimation of top wealth. However, national and financial 
accounts of household wealth might be flawed by uncertainty related to the estimation, in particular with respect to non-financial assets, corporate shares in non-quoted firms, and financial assets abroad. This is also true for Germany. The differences between the national and financial accounts statistics and results from household surveys should by analyzed in detail for the different components of household wealth and liabilities.

\section{Summary and conclusion}

In this study we analyze the top tail of the wealth distribution and construct an integrated database for in Germany, France, Spain, and Greece that better represents the top wealth concentration. We use the Eurosystem's Household Finance and Consumption Survey (HFCS). Since top wealth is likely to be underrepresented in household surveys we integrate the big fortunes from rich lists provided by business media. We use the Forbes list of billionaires, and national lists, in particular from the German business periodical manager magazin (2011), from the French magazine Challenges (2010), from the Spanish newspaper el mundo (2009), and the Greek rich list (2009/10).

Following Vermeulen (2014) we combine the household survey data with the rich lists to jointly estimate a Pareto distribution for the top tail of wealth in both countries. After checking different thresholds for the Pareto distribution of 0.5, 1 and 2 million Euros, we set it to 0.5 million Euros. Instead of the Forbes list we mainly rely on national rich lists since they represent a broader base for the big fortunes. Moreover, we check different specifications of the national rich lists for Germany and France and prefer to use the top 200 richest households. The inclusion of the national rich lists instead of the Forbes list substantially affects the estimates for the Pareto coefficient $\alpha$, resulting in a lower value and thus in a higher top wealth concentration in all subsamples. This is especially the case in France and Spain for which the Forbes list contains only few observations. Generally, Germany shows a higher top wealth concentration than France and Spain. The results for Greece are ambiguous since the data do not show clear concentration patterns.

We impute synthetic household net wealth for the missing rich based on the preferred Pareto coefficients for each country. The resulting database could be used for detailed distribution or microsimulation analyses. We show the entire distribution of net wealth up to the top 0.1 percent, both for the HFCS alone and including the imputed top wealth. For Germany the results suggest a high impact of the missing rich. The share of the top percentile in household wealth jumps up from 24 percent based on the HFCS alone to 33 percent after top wealth imputation, 
the share of the top 0.1 percent hikes up from 4 percent to 17 percent, the Gini coefficient for the wealth distribution increases from 0.75 to 0.78 . For France and Spain we find smaller effects of the imputation since rich households are better captured in the HFCS survey for these countries. The share of total net wealth held by the top 1 percent in France increases by 3 percentage points to 21 percent, the Gini coefficient increases from 0.67 to 0.69 . In Spain, the effect of the adjustment for the missing rich is even smaller. The wealth share of the top 1 percent increases by 2 percentage points, the Gini coefficient rises from 0.57 to 0.58 .

It has to be mentioned that the results of our analysis should be interpreted with caution. Uncertainty emerges from the estimation strategy of the top wealth concentration, which relies on the Pareto distribution, and from measurement errors in household wealth, both with the HFCS and the rich lists. With respect to the HFCS, we are dealing with the first wave which might be plagued with some shortcomings to be improved in the subsequent waves. Regarding the rich lists, the reliability is contentious and often debated in the public. We suppose that the listings rather underreport the very top wealth concentration with respect to some selectivity in favor of corporate wealth and against private wealth, such as real estate properties and financial portfolios. It is hard to evaluate the self-assessed property valuations of the survey respondents or the valuations of the properties collected in the rich lists. We have no evidence of systematic biases in this respect.

Actually, these issues indicate substantial need for research. Tax files from wealth taxation or disclosed financial statements of large family-owned corporations might be better utilized for top wealth research. Sampling design, survey strategy and field work of voluntary household surveys might be improved to better collect data from the wealthy strata of the population.

The database of our analysis refers to the period between 2008 and 2011. Since that time the substantial changes in macroeconomic performance should have altered both wealth aggregates and distribution. The sharp recession in Spain and Greece could have markedly reduced the value of real estate and business properties in these countries. In Germany, the opposite is true. Historically low interest rates discriminate fixed-income securities such as bank deposits or pension plans, and favor investments in real assets such as real estate, businesses, or corporate shares. As the latter dominate top wealth strata, the wealth distribution might have concentrated further, at least in Germany and France. Counterfactual microsimulation analyses could shed light on the distributional impact involved. Moreover, our integrated database could be used for the analyses of redistribution policies, for instance wealth taxation or programs to promote housing ownership and capital formation. 


\section{References}

Alvaredo, Facundo, Emmanuel Saez (2009): Income and Wealth Concentration in Spain in a Historical and Fiscal Perspective. Journal of the European Economic Association 7, 1140-1167.

Azpitarte, Francisco (2010): The household wealth distribution in Spain: The role of housing and financial wealth. Hacienda Pública Española / Revista de Economía Pública, 194-(3/2010), 65-90.

Bach, Stefan, Martin Beznoska, Viktor Steiner (2014): A Wealth Tax on the Rich to Bring Down Public Debt? Revenue and Distributional Effects of a Capital Levy in Germany. Fiscal Studies 35, 67-89.

Brzezinski, Michal (2013): Do wealth distributions follow power laws? Evidence from "rich lists". Faculty of Economic Sciences, University of Warsaw.

Burkhauser, Richard V., Shuaizhang Feng, Stephen P. Jenkins, Jeff Larrimore (2012): Recent Trends in Top Income Shares in the USA: Reconciling Estimates from March CPS and IRS Tax Return Data. Review of Economics and Statistics 94: 371-388.

Challenges (2010): Les 500 plus grandes fortunes professionnelles de France. Challenges 220 July, $8^{\text {th }}$ 2010.

Challenges (2012): Comment évalue-t-on leur patrimoine?

Clauset, Aaron, Shalizi Cxosma Rohilla, M.E.J. Newman (2009): Power-law distributions in empirical data. SIAM Review 51: 661-703.

Cowell, Frank A. (2009): Measuring inequality. Oxford University Press.

Davies, James B. (1993): The distribution of wealth in Canada. Research in Economic Inequality, vol. 4, 159-180.

Davies, James B., Anthony Shorrocks (1999): The distribution of wealth. Handbook of Income Distribution. Edited by A. B. Atkinson and F. Bourguignon. Volume 1, Chapter 11: 223-254.

Davies, James B., Susanna Sandstrom, Anthony Shorrocks, Edward N. Wolff (2010): The level and distribution of global household wealth. Economic Journal 121: 223-254.

El mundo (2009): LOS 100 MÁS RICOS DE ESPAÑA, El mundo magazine 532.

Eckerstorfer, Paul, Johannes Halak , Jakob Kapeller, Bernhard Schütz, Florian Springholz, Rafael Wildauer (2015): Correcting for the Missing Rich: An Application to Wealth Survey Data. Review of Income and Wealth, online first.

Embrechts, Paul, Claudia Klüppelberg, Thomas Mikosch (1997): Modelling Extremal Events for Insurance and Finance. Springer.

European Central Bank (ECB) (2013a): The Eurosystem household finance and consumption survey. Methodological report for the first wave. European Central Bank, Statistic Papers 1.

European Central Bank (ECB) (2013b): The Eurosystem household finance and consumption survey. Results from the first wave. European Central Bank, Statistic Papers 2.

Forbes (2014): The World's Billionaires 2014. See http://www.forbes.com/billionaires/

Förster, Michael, Ana Llena-Nozal, Vahé Nafilyan: Trends in Top Incomes and their Taxation in OECD Countries. OECD Social, Employment and Migration. Working Papers, No. 159, OECD Publishing.

Gabaix, Xavier (2009): Power Laws in Economics and Finance. Annual Review of Economics, 255293.

Greek rich list (2009/10): Greek Rich List. The Official Publication Profiling the World's Greek Millionaires. Issue Three. 
Kleiber, Christian, Samuel Kotz (2003): Statistical Size Distributions in Economics and Actuarial Sciences. Wiley.

manager magazin (2011): Die 500 reichsten Deutschen (The 500 richest Germans). manager magazin spezial Oktober 2011. See Wikipedia: Liste der 500 reichsten Deutschen.

Piketty, Thomas (2013): Capital in the Twenty-First Century. Harvard University Press.

Raub, Brian, Barry Johnson, Joseph Newcomb (2010): A Comparison of Wealth Estimates for America's Wealthiest Descendants Using Tax Data and Data from the Forbes 400. National Tax Association Proceedings, 103rd Annual Conference on Taxation (2010): 128-135.

Tiefensee, Anita, Markus M. Grabka (2014): Comparing Wealth - Data Quality of the HFCS. DIW Berlin, Discussion Paper 1427.

Vermeulen, Philip (2014): How fat is the top tail of the wealth distribution? European Central Bank, Working Paper Series 1692.

Zucman, Gabriel (2008): Les hauts patrimoines fuient-ils l'ISF ? Une estimation sur la période 19952006. Ecole d'Economie de Paris - Master Analyse et politique économiques. 


\section{Appendix}

Table A1: Assets and liabilities of households in Germany according to national and financial accounts, 2010

End-of-year level

\begin{tabular}{|c|c|c|c|c|c|}
\hline Assets & $\begin{array}{c}\text { billion } \\
\text { Euro }\end{array}$ & $\%$ & Liabilities & $\begin{array}{l}\text { billion } \\
\text { Euro }\end{array}$ & $\%$ \\
\hline Non-financial assets & 5844 & 51.8 & Loan and other liabilities ${ }^{2)}$ & 1519 & 13.5 \\
\hline Dwellings & 3584 & 31.7 & Consumer loans & 211 & 1.9 \\
\hline Land underlying buildings & 1673 & 14.8 & Mortgage loans & 1040 & 9.2 \\
\hline Other buildings & 393 & 3.5 & Entrepreneurial loans & 256 & 2.3 \\
\hline Land underlying other buildings & 50 & 0.4 & Other liabilities & 12 & 0.1 \\
\hline Other non-financial assets ${ }^{1)}$ & 143 & 1.3 & & & \\
\hline Financial assets $^{2}$ ) & 4541 & 40.2 & & & \\
\hline Currency and deposits & 1809 & 16.0 & & & \\
\hline Mutual funds shares & 405 & 3.6 & & & \\
\hline Claims on insurance corporations ${ }^{3)}$ & 1397 & 12.4 & & & \\
\hline Short-term claims & 71 & 0.6 & & & \\
\hline Longer-term claims & 1326 & 11.7 & & & \\
\hline with life insurance companies & 788 & 7.0 & & & \\
\hline with health insurance schemes & 167 & 1.5 & & & \\
\hline with pension funds & 371 & 3.3 & & & \\
\hline Company pension commitments & 284 & 2.5 & & & \\
\hline Securities & 645 & 5.7 & Net wealth & 9771 & 86.5 \\
\hline Bonds, money market papers & 229 & 2.0 & & & \\
\hline Shares & 234 & 2.1 & & & \\
\hline Other equity & 182 & 1.6 & $\begin{array}{l}\text { Net wealth less company pension } \\
\text { commitments, claims with health }\end{array}$ & & \\
\hline Consumer durables of households & 906 & 8.0 & insurance schemes & 8948 & 79.3 \\
\hline Total & 11291 & 100.0 & Total & 11291 & 100.0 \\
\hline
\end{tabular}


Table A2: Assets and liabilities of households1) in France according to national and financial accounts, 2010

End-of-year level

\begin{tabular}{|c|c|c|c|c|c|}
\hline Assets & $\begin{array}{c}\text { billion } \\
\text { Euro }\end{array}$ & $\%$ & Liabilities & $\begin{array}{l}\text { billion } \\
\text { Euro }\end{array}$ & $\%$ \\
\hline Non-financial assets & 7462 & 65.1 & Financial liabilities & 1255 & 11.0 \\
\hline Buildings and land & 7003 & 61.1 & Loans & 1066 & 9.3 \\
\hline Housing & 3262 & 28.5 & Equity liabilities & 7 & 0.1 \\
\hline Other buildings & & & Other financial liabilities & 182 & 1.6 \\
\hline and civil engineering & 176 & 1.5 & & & \\
\hline Developed land & 3565 & 31.1 & & & \\
\hline Other non-financial assets ${ }^{2)}$ & 459 & 4.0 & & & \\
\hline Financial assets ${ }^{3)}$ & 3994 & 34.9 & & & \\
\hline Currency and deposits & 1159 & 10.1 & & & \\
\hline Securities other than shares & & & & & \\
\hline excluding financial derivatives & 62 & 0.5 & Net wealth & 10201 & 89.0 \\
\hline Loans & 27 & 0.2 & & & \\
\hline Equities and mutual fund shares & 1026 & 9.0 & & & \\
\hline Insurance technical reserves & 1469 & 12.8 & Net wealth less 50 percent of & & \\
\hline Other financial assets & 251 & 2.2 & insurance technical reserves & 9467 & 82.6 \\
\hline Total & 11456 & 100.0 & Total & 11456 & 100.0 \\
\hline
\end{tabular}

Table A3: Assets and liabilities of households1) in Spain according to national and financial accounts, 2009

End-of-year level

\begin{tabular}{|c|c|c|c|c|c|}
\hline Assets & $\begin{array}{c}\text { billion } \\
\text { Euro }\end{array}$ & $\%$ & Liabilities & $\begin{array}{l}\text { billion } \\
\text { Euro }\end{array}$ & $\%$ \\
\hline \multirow[t]{2}{*}{ Non-financial assets ${ }^{2)}$} & 5881 & 77.4 & Financial liabilities & 948 & 12.5 \\
\hline & & & Loans & 906 & 11.9 \\
\hline Financial assets & 1716 & 22.6 & Other liabilities & 42 & 0.6 \\
\hline Currency and deposits & 815 & 10.7 & & & \\
\hline Debt securities & 43 & 0.6 & & & \\
\hline Equity and investment fund shares & 537 & 7.1 & & & \\
\hline standardised guarantees & 277 & 3.6 & Net wealth & 6649 & 87.5 \\
\hline Other financial assets ${ }^{3)}$ & 44 & 0.6 & & & \\
\hline Total & 7597 & 100.0 & Total & 7597 & 100.0 \\
\hline
\end{tabular}


Table A4: Assets and liabilities of households1) in Greece according to financial accounts, 2009

End-of-year level

\begin{tabular}{|c|c|c|c|c|c|}
\hline Assets & $\begin{array}{l}\text { billion } \\
\text { Euro }\end{array}$ & $\%$ & Liabilities & $\begin{array}{l}\text { billion } \\
\text { Euro }\end{array}$ & $\%$ \\
\hline Financial assets & 297.4 & 100.0 & Financial liabilities & 136.6 & 45.9 \\
\hline Currency and Deposits & 211.5 & 63.0 & Loans & & \\
\hline Debt securities & & & Short-term & 19.4 & 6.5 \\
\hline Short-term & 0.8 & 0.3 & Long-term & 103.8 & 34.9 \\
\hline Long-term & 15.2 & 4.5 & Other accounts payable ${ }^{2)}$ & 13.4 & 4.5 \\
\hline \multicolumn{6}{|l|}{$\begin{array}{l}\text { Equity and investment fund shares } \\
\text { or units }\end{array}$} \\
\hline Listed Shares & 21.9 & 6.5 & & & \\
\hline Unlisted Shares and other equity & 11.1 & 3.3 & & & \\
\hline Investment fund shares & 5.5 & 1.6 & & & \\
\hline Insurance, pension and & & & & & \\
\hline standardised gurantees & 11.4 & 3.4 & Net financial wealth & 160.8 & 54.1 \\
\hline Other accounts receivable ${ }^{2)}$ & 20.0 & 5.9 & & & \\
\hline Total & 297.4 & 100.0 & Total & 297.4 & 100.0 \\
\hline
\end{tabular}

